\title{
The Effect of Intensity and Duration on the Light-Induced Sodium and Potassium Currents in the Hermissenda Type B Photoreceptor
}

\author{
Kim T. Blackwell \\ School of Computational Sciences and the Krasnow Institute for Advanced Study, George Mason University, Fairfax, \\ Virginia 22030
}

\begin{abstract}
Light duration and intensity influence classical conditioning in Hermissenda through their effects on the light-induced currents. Furthermore, the contribution of voltage-dependent potassium currents to the long-lasting depolarization in type $B$ photoreceptors depends on light-induced currents active at resting potentials. Thus, the present study measures the effect of holding potential, duration, and intensity on the light-induced currents in discontinuous single-electrode voltage clamp mode. Three distinct current components are distinguished by their temporal and voltage characteristics and sensitivity to pharmacological agents. One current component is a transient sodium current, $I_{\text {Nalgt }}$; another is a plateau sodium current, $I_{\text {plateau }}$, which persists for the duration of the light stimulus. Substitution of trimethylammonium chloride for sodium reduces both currents equally, suggesting that $I_{\text {plateau }}$ represents
\end{abstract}

Hermissenda crassicornis is a model system for studying classical conditioning because many of the behavioral and biophysical properties are similar to those in mammals (Lederhendler and Alkon, 1989; Matzel et al., 1990). Classical conditioning in Hermissenda uses light as the conditioned stimulus and turbulence as the unconditioned stimulus. Intracellular recordings demonstrate that classical conditioning causes the following changes to type $\mathrm{B}$ photoreceptors: an increase in input resistance $\left(R_{\mathrm{N}}\right)$, an enhanced long-lasting depolarization (LLD) in response to light (Crow and Alkon, 1980; Farley and Alkon, 1982; West et al., 1982; Frysztak and Crow, 1994), a reduction in the calcium-dependent, $I_{\mathrm{KCa}}$, and transient, $I_{\mathrm{A}}$, potassium currents (Alkon et al., 1982, 1984, 1985), a reduction in the calcium current (Collin et al., 1988), translocation of protein kinase C (McPhie et al., 1993; Muzzio et al., 1997), and facilitation of the IPSP in type A photoreceptors by type B photoreceptor action potentials (Frysztak and Crow, 1994, 1997; Schuman and Clark, 1994). Computer models (Sakakibara et al., 1993; Fost and Clark, 1996) demonstrate that a reduction in $I_{\mathrm{KCa}}$ can cause the enhanced LLD and increase in spike frequency, and a reduction in $I_{\mathrm{A}}$ can cause spike broadening and an increase in neurotransmitter release at type A to type B photoreceptor synapses.

\footnotetext{
Received Oct. 9, 2001; revised Feb. 14, 2002; accepted Feb. 19, 2002.

This work is supported by National Science Foundation Grant IBN 0077509 and National Institute of Mental Health Grant K21 MH01141. I thank Lou Matzel for demonstrating the axotomy and SEVC technique and Brent Elliot for assistance in data analysis.

Correspondence should be addressed to Kim T. Blackwell, School of Computational Sciences and the Krasnow Institute for Advanced Study, George Mason University, Rockfish Creek Lane, MS 2A1, Fairfax, VA 22030. E-mail: avrama@gmu.edu.

Copyright (ㄷ) 2002 Society for Neuroscience $\quad 0270-6474 / 02 / 224217-12 \$ 15.00 / 0$
}

partial inactivation of $I_{\text {Nalgt }}$. The third current component is a prolonged reduction in potassium currents, $I_{\mathrm{KIgt}}$; it is accompanied by an increase in input resistance, and it appears at potentials close to rest. An increase in light duration or intensity causes an increase in the peak conductance of both $I_{\text {Nalgt }}$ and $I_{\text {Klgt }}$. Latency of $I_{\text {Nalgt }}$ is decreased by intensity, whereas rise time is increased by duration. An increase in light duration or intensity causes an increase in the time-to-peak and duration of $I_{\mathrm{Klgt}}$. Characteristics of these currents suggest that $I_{\mathrm{Klgt}}$ is responsible for the long-lasting depolarization seen after light termination, and thus plays a role in classical conditioning.

Key words: associative learning; $\mathrm{K}^{+}$currents; photoreceptors; phototransduction; classical conditioning; leak currents; sodium currents

A limitation of these computer models is that the equations for the light-induced currents are not based on voltage-clamp recordings. The early, transient light-induced current $\left(I_{\text {Nalgt }}\right)$ is carried by sodium ions (Alkon and Sakakibara, 1985). It is linearly related to holding potential, with an extrapolated reversal potential of $30-40 \mathrm{mV}$. The later, prolonged light-induced current $\left(I_{\mathrm{Klgt}}\right)$ is sensitive to the extracellular potassium concentration, and thus is carried by potassium ions (Alkon and Sakakibara, 1985).

A more recent photoreceptor model (Blackwell, 2000) includes equations for $I_{\mathrm{Nalgt}}$ based on voltage-clamp recordings. This model does not include an explicit $I_{\mathrm{K} \text { gt }}$ because investigators have concluded that $I_{\mathrm{KCa}}$ is equivalent to $I_{\mathrm{Klgt}}$ based on its sensitivity to calcium, and because both currents are affected by light stimulation. However, simulations show that without an explicit $I_{\mathrm{K} \operatorname{lgt}}$, the simulated light response does not resemble the experimentally measured light response, suggesting that $I_{\mathrm{Klgt}}$ is distinct from $I_{\mathrm{KCa}}$. In particular, a prolonged light-induced current is required to produce the LLD. Simulations also suggest that, without the "baseline" LLD, a reduction in $I_{\mathrm{KCa}}$ cannot cause an enhancement of the LLD, because $I_{\mathrm{KCa}}$ is not active at membrane potentials more negative than $-40 \mathrm{mV}$, the potential of the LLD. Thus, the present study characterizes the prolonged light-induced current that may underlie the baseline LLD and allow expression of classical conditioning.

The effect of light intensity and duration on the light-induced currents has not been systematically investigated. Such information is desperately needed because a variety of light durations and intensities are used for behavioral experiments and in vitro conditioning. The interaction between the light and turbulence stimuli may depend on the amplitude and time course of the light- 
induced currents, which in turn are affected by the duration and intensity of the light. Therefore, the present study measures the effect of duration and intensity on $I_{\mathrm{K} \operatorname{lgt}}$ and $I_{\mathrm{Nalgt}}$.

\section{MATERIALS AND METHODS}

Hermissenda were obtained from Sea Life Supply (Sand City, CA) and Marinus (Los Angeles, CA). They were housed in groups of five or less in a refrigerated aquarium containing artificial seawater (ASW) chilled to $12^{\circ} \mathrm{C}$. The animals were maintained on a $12 \mathrm{hr}$ light/dark cycle, and they were fed a piece of cooked frozen mussel $4 \mathrm{~d} /$ week. Experiments were performed during the middle $8 \mathrm{hr}$ of the light cycle.

An in vitro preparation was used to measure light-induced currents in voltage-clamp mode. The Hermissenda was killed by a razor cut just caudal to the rhinophores, and then the circumesophageal nervous system was removed by cutting the nerves that exit the ganglia and curve around the buccal crest. Pins were laid across the nerves and connectives of the ganglia to fix the nervous system within a shallow chamber made by an oval ring of grease on a glass microscope slide. The optic nerve was cut at the point where it emerged from the optic ganglion and entered the cerebropleural ganglion using an ultrafine dissecting scissor (Fine Science Tools, Foster City, CA) or a razor blade fragment. This had the effect of eliminating $\mathrm{Na}^{+}$spikes and removing the spatially extended axon and terminal branches. To facilitate penetration of the microelectrode, connective tissue was dissolved by incubating with Protease (type IX, $10 \mathrm{mg} / \mathrm{ml}$; Sigma, St. Louis, MO) for $12 \mathrm{~min}$ at $25^{\circ} \mathrm{C}$. The reaction was stopped by rinsing with $20 \mathrm{ml}$ of ASW at $4^{\circ} \mathrm{C}$. During the experiment the nervous system was continuously perfused with chilled $\left(18^{\circ} \mathrm{C}\right) \mathrm{ASW}$ containing (in $\mathrm{mM}$ ): $430 \mathrm{NaCl}, 10 \mathrm{KCl}, 10 \mathrm{CaCl}_{2}, 50 \mathrm{MgCl}_{2}$, and 10 HEPES-Na adjusted to $\mathrm{pH} 7.6$ with $\mathrm{HCl}$.

The light stimulus was provided via a fiber optic bundle aimed at the nervous system. The light source was a tungsten bulb filtered through a Kodak Wratten filter \#47 (passband 380-520 nm) resulting in an intensity of $400 \mu \mathrm{W} / \mathrm{cm}^{2}$ (measured with a Tektronix J17 photometer) when no neutral density filter (ND 0) was used. Light duration was controlled with a computer-controlled shutter. The intensity of the light was controlled with neutral density filters, the transmission of which ranged from 10 (ND 1) to $0.1 \%$ (ND 3).

Type B photoreceptors, identified by their position within the eye, were impaled and then dark-adapted for $10 \mathrm{~min}$ before measuring input resistance, resting potential, and peak generator potential. Input resistance was computed from the voltage change measured during the last $100 \mathrm{msec}$ of a series of $400 \mathrm{msec}$ current injection pulses (Fig. 1). Photoreceptors with input resistance of $>5 \mathrm{M} \Omega$, resting potential more negative than $-30 \mathrm{mV}$, and generator potential $>10 \mathrm{mV}$ were accepted for experiments. Capacitance compensation, anti-alias, sample rate, gain, and phase were adjusted for discontinuous, single-electrode voltageclamp mode (SEVC), as described in the Axoclamp 2B users manual (Axon Instruments, Foster City, CA). By minimizing the fluid level and using an aluminosilicate glass micropipette of tip resistance between 10 and $15 \mathrm{M} \Omega$ (when filled with $\mathrm{KCl}$ ), a mean sample rate of $15.7 \pm 1.7 \mathrm{kHz}$ and mean gain of $4.4 \pm 1.23$ were achieved. Measurements of lightinduced currents were begun no sooner than after $15 \mathrm{~min}$ of dark adaptation.

The voltage dependence of the light-induced currents was measured for both $30 \mathrm{msec}$ light stimuli and $3 \mathrm{sec}$ light stimuli. Cells were clamped at potentials ranging from -100 to $0 \mathrm{mV}$ for $10 \mathrm{sec}$ before the light stimulus to allow the voltage-dependent currents to reach their steady-state values. To ensure a constant level of dark adaptation, the response to a $30 \mathrm{msec}$ light was measured every $2 \mathrm{~min}$, and the response to a $3 \mathrm{sec}$ light was measured every 3 min. Measurements were performed once in ASW and then repeated while perfusing with $0 \mathrm{Na}^{+}-460 \mathrm{~mm}$ trimethyl ammonium chloride (TMA) ASW, which blocks $I_{\text {Nalgt }}$ or while perfusing with 0 $\mathrm{Ca}^{2+}-10 \mathrm{mM} \mathrm{Ba}^{2+}$ ASW.

The effect of light duration and intensity on $I_{\text {Nalgt }}$ was measured at a clamp potential of $-80 \mathrm{mV}$ in ASW. The effect of light duration and intensity on $I_{\mathrm{Klgt}}$ was measured at a clamp potential of $-20 \mathrm{mV}$ in 0 $\mathrm{Na}^{+}-460 \mathrm{~mm}$ TMA ASW. Repeated presentation of light stimuli sometimes sensitized the photoreceptor and increased the light-induced currents. This sensitization opposed and obscured the decrease in current expected from a decrease in light amplitude. To minimize this effect, measurements of the effect of light intensity were counterbalanced; half the experiments presented dim lights first, and the other half presented brighter lights first.

Statistical analysis was performed using the software SAS (SAS Insti-
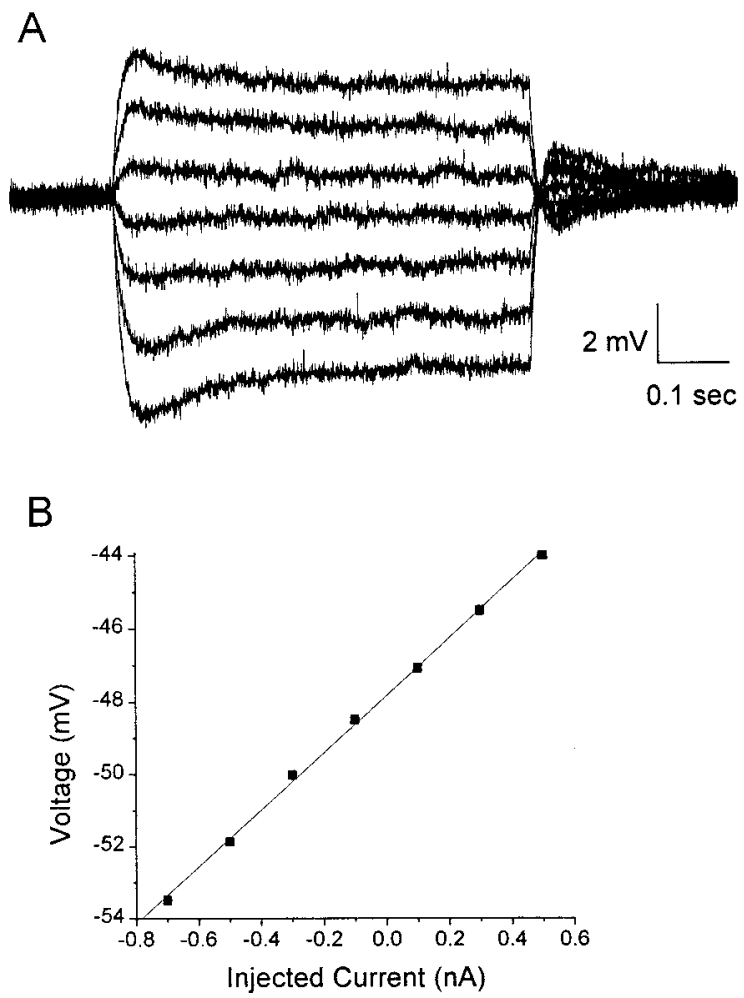

Figure 1. Measurement of input resistance in discontinuous current clamp. $A$, Response to $400 \mathrm{msec}$ current injection pulses between -0.7 and $0.5 \mathrm{nA}$. Steady-state voltage is the mean voltage measured during the last $100 \mathrm{msec}$ of current injection. Resting potential for this cell was -48 $\mathrm{mV}$. B, Plot of steady-state voltage versus injected current. Input resistance, $8 \mathrm{M} \Omega$ for this cell, is the slope of the line.

Table 1. Mean physiological parameters of cells that met criteria and were included in the study

Measurement Mean $\pm \mathrm{SE}$

Generator potential $16.66 \pm 0.68 \mathrm{mV}$

Resting potential $-44.21 \pm 1.11 \mathrm{mV}$

Input resistance (current clamp, at resting potential)

Input resistance (voltage clamp, at $-60 \mathrm{mV}$ )

$8.36 \pm 0.37 \mathrm{M} \Omega$

$8.42 \pm 0.35 \mathrm{M} \Omega$

tute, Inc., Cary, NC). The SAS procedure general linear models (GLM) was performed to assess differences among the cell groups. Where the model was significant, the ad hoc test least squares means was used to identify which groups differed significantly. The procedure REG was used to estimate reversal potentials; the procedure CORR was used to compute correlations.

\section{RESULTS}

\section{Basic physiological parameters of cells included in study}

A total of 43 cells met the criteria for $R_{\mathrm{N}}$, resting potential, and generator potential, and were included in the study. Table 1 lists the overall mean generator potential, resting potential, $R_{\mathrm{N}}$ measured in current clamp (at dark-adapted resting potential) and $R_{\mathrm{N}}$ measured in voltage clamp at $-60 \mathrm{mV}$ for these cells. The resting membrane potential $(-44 \mathrm{mV})$, generator potential $(16.7 \mathrm{mV})$, and $R_{\mathrm{N}}(8.5 \mathrm{M} \Omega)$ are lower than that measured by others (Matzel and Rogers, 1993) and by the author (Blackwell and Alkon, 1999) using a single-electrode technique. The low values are partly 
(A) ASW

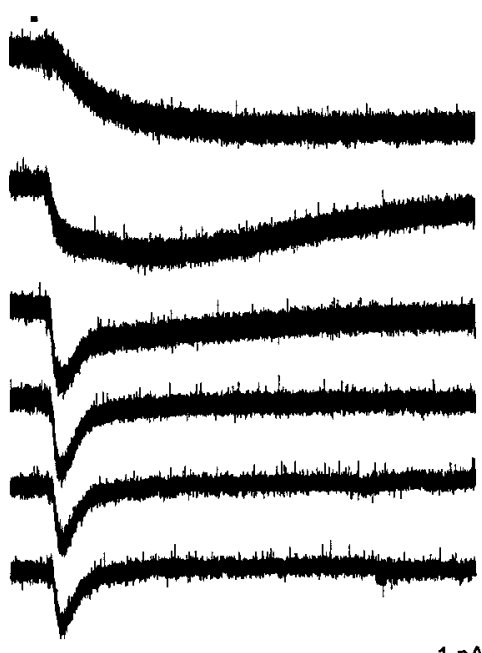

(B) $0 \mathrm{Na}^{+}-\mathrm{TMA}$ ASW

1

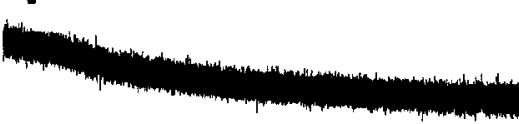

$-17$

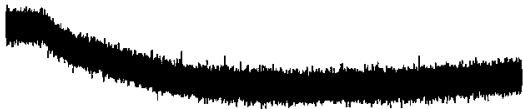

$-37$

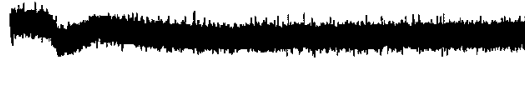

$-56$

$-76$

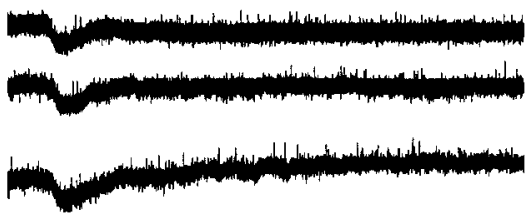

(C) ASW Wash
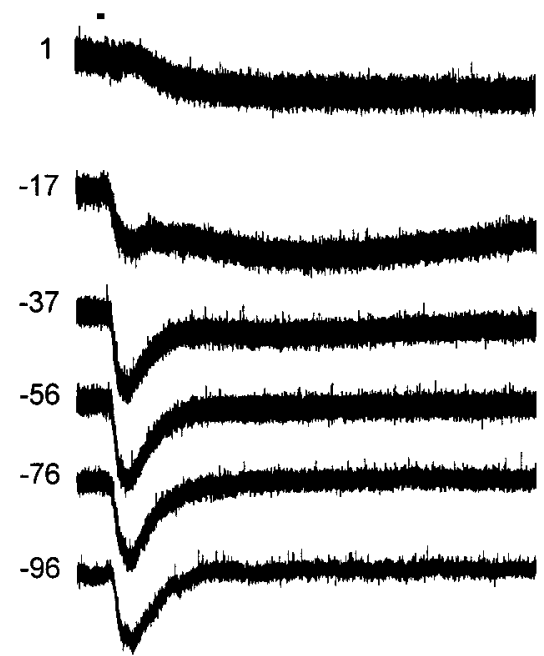

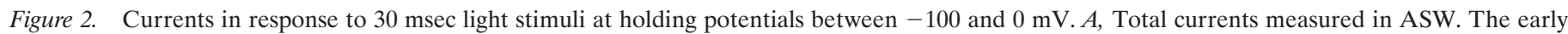

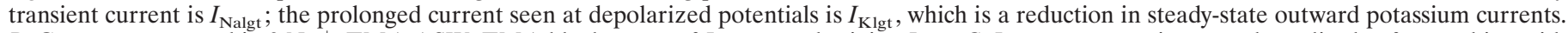

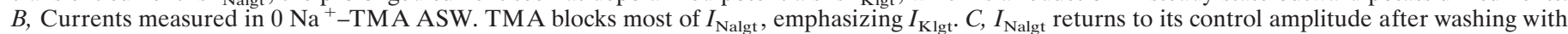
ASW for $5 \mathrm{~min}$. The bars indicates when the light stimulus occurred. Traces are offset by an arbitrary amount.

caused by the axotomy, which decreases the integrity of the membrane. A second cause of the low $R_{\mathrm{N}}$ and membrane potential is the low pipette resistance required to achieve an adequate sample rate and gain for the SEVC. The resting membrane potential, generator potential, and $R_{\mathrm{N}}$ in the present study are comparable with values reported in some two electrode voltageclamp studies (Alkon et al., 1984; Huang and Farley, 2001) that also use axotomy and low pipette resistance.

Seventeen cells were used for measuring the effect of intensity and duration at a single-clamp potential. Of these, seven were clamped at $-20 \mathrm{mV}$ in $0 \mathrm{Na}^{+}-460 \mathrm{~mm}$ TMA ASW to isolate $I_{\mathrm{Klgt}}$, and 10 were clamped at $-80 \mathrm{mV}$ in ASW to isolate $I_{\mathrm{Nalgt}}$.
To evaluate the voltage dependence of the light-induced currents, seven cells were stimulated with $30 \mathrm{msec}$ duration lights at a range of holding potentials, and 17 cells were stimulated with $3 \mathrm{sec}$ duration lights at a range of holding potentials. Two additional cells, plus three of the cells used for the $-20 \mathrm{mV}$ protocols, were used to measure the change in $R_{\mathrm{N}}$ during and after a light stimulus. Other than these three cells, all other cells were used for a single protocol only. The only significant difference among these groups was the value of $R_{\mathrm{N}}$ measured after $15 \mathrm{~min}$ of dark adaptation in voltage clamp $(F=5.38 ; p=0.0036)$. Post hoc comparisons showed that the mean $R_{\mathrm{N}}$ of the group of cells clamped at $-20 \mathrm{mV}(10.2 \mathrm{M} \Omega)$ was significantly different than the
(A) ASW

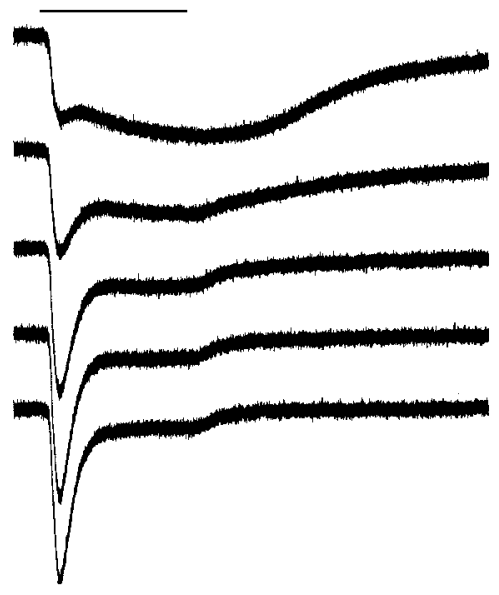

(B) $0 \mathrm{Na}^{+}$-TMA ASW

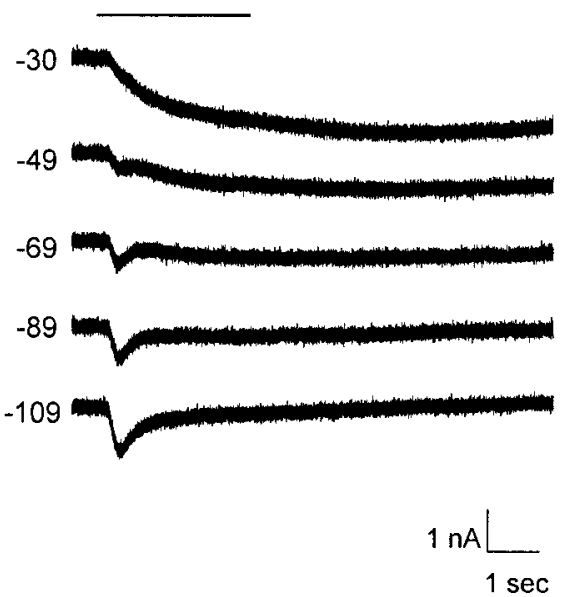

(C) ASW Wash

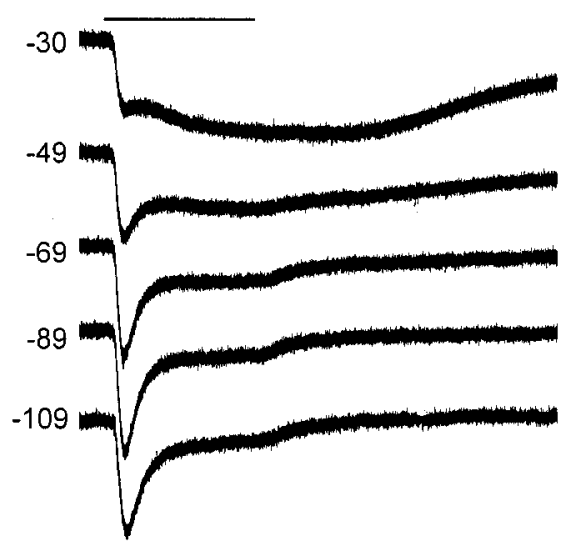

Figure 3. Currents in response to $3 \mathrm{sec}$ light stimuli at holding potentials between -100 and $0 \mathrm{mV}$. A, Total currents measured in ASW. In addition to $I_{\mathrm{Nalgt}}$ and $I_{\mathrm{Klgt}}$, a third current component, $I_{\text {plateau }}$, is visible between potentials of -100 and $-40 \mathrm{mV}$. The duration of $I_{\text {plateau }}$ corresponds to that of the light stimulus. $B$, Currents measured in $0 \mathrm{Na}^{+}-$TMA ASW. TMA blocks most of $I_{\text {Nalgt }}$ and all of $I_{\text {plateau }} \cdot C$, After washing with ASW for 5 min, $I_{\text {plateau }}$ returns, and $I_{\text {Nalgt }}$ increases toward its control amplitude. The bars indicates when the light stimulus occurred. Traces are offset by an arbitrary amount. 
(A)

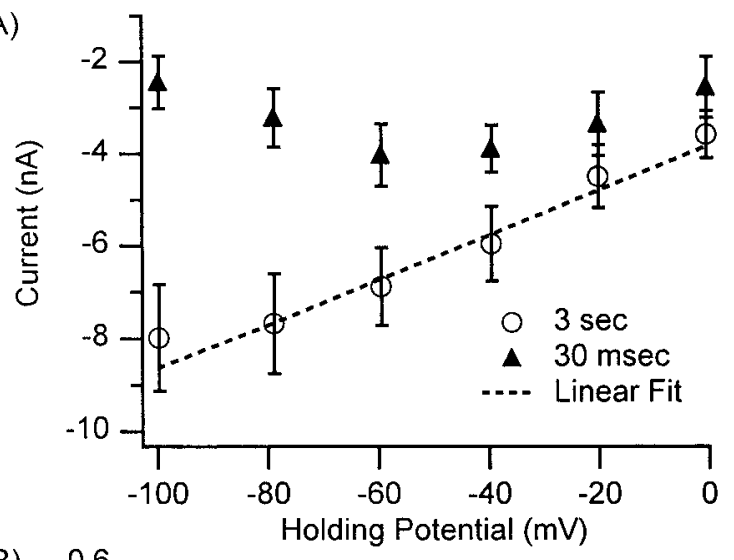

(B)

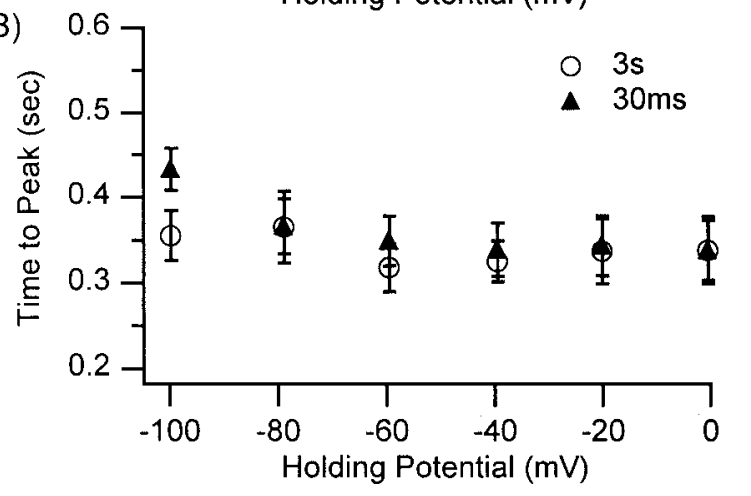

(C)

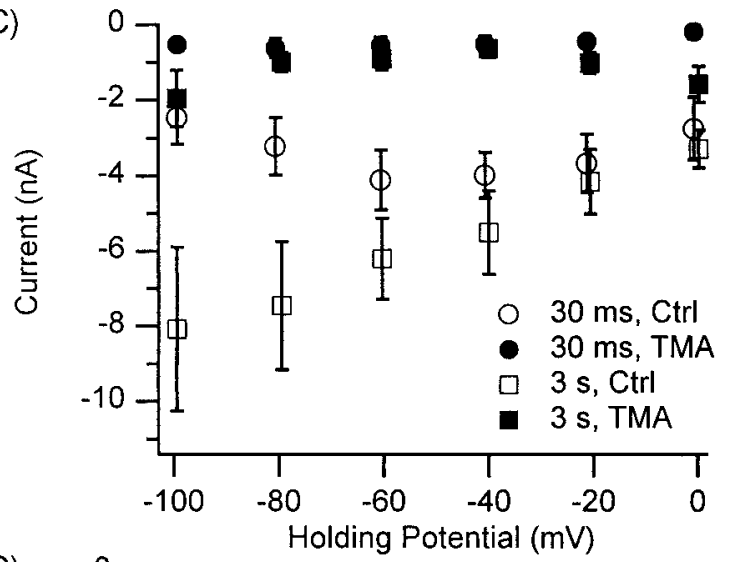

(D)

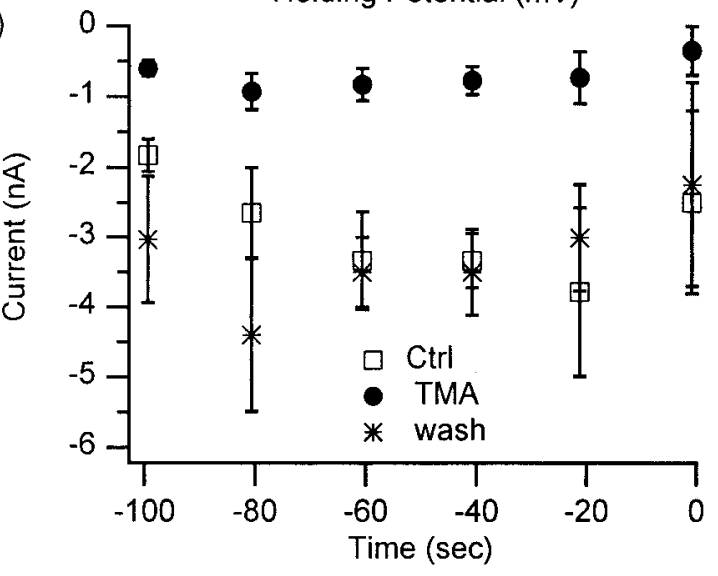

Figure 4. Characteristics of $I_{\text {Nalgt }}$. A, Mean peak conductance of $I_{\text {Nalgt }}$ in response to $30 \mathrm{msec}$ stimuli (solid triangles) and $3 \mathrm{sec}$ stimuli (open circles) as a function of holding potential. The dashed line is the regression line computed between individual peak $I_{\text {Nalgt }}$ measurements and holding potential. Error bars indicated 1 SE. B, Mean time-to-peak of $I_{\text {Nalgt }}$ in mean $R_{\mathrm{N}}$ of the group clamped at $-80 \mathrm{mV}(6.7 \mathrm{M} \Omega ; p=0.0007)$. There was no significant difference among groups in resting potential $(F=0.23)$, generator potential $(F=2.17)$, or $R_{\mathrm{N}}$ measured after $10 \mathrm{~min}$ of dark adaptation in current-clamp mode $(F=1.29)$.

\section{Three current components revealed by voltage-clamp measurements}

Voltage-clamp measurements of the light-induced currents revealed three distinct components that were separated by their temporal and voltage characteristics. Two of the current components were seen at hyperpolarized potentials. The first component was a transient current, $I_{\text {Nalgt }}$, seen with $30 \mathrm{msec}$ (Fig. $2 A$ ) and $3 \mathrm{sec}$ duration light stimuli (Fig. $3 A$ ). Previous reports identified this as a sodium current, because it decreased with depolarization and was eliminated when sodium was replaced with TMA. The second component was a plateau current, $I_{\text {plateau }}$, that was seen with $3 \mathrm{sec}$ light stimuli and persisted for the duration of the light stimulus (Fig. 3A). An additional current component, $I_{\mathrm{K} \text { lgt }}$, was seen at depolarized potentials and persisted for many seconds after light termination. It appeared to be an inward current, but previous reports (Alkon and Sakakibara, 1985) identified this as a reduction in steady-state outward potassium currents, because it increased with depolarization and was sensitive to the potassium concentration in the bath.

\section{Characterization of the light-induced sodium currents}

The light-induced currents were measured at holding potentials between -100 and $0 \mathrm{mV}$ in steps of $20 \mathrm{mV}$ to evaluate their voltage dependence and reversal potential. A graph of the mean peak $I_{\text {Nalgt }}$ versus holding potential for $3 \mathrm{sec}$ duration light stimuli (Fig. $4 A$, open circles) verified previous reports demonstrating no voltage dependence of this current. The current amplitude measured at $-100 \mathrm{mV}$ was similar to that at $-80 \mathrm{mV}$, probably because this first $3 \mathrm{sec}$ duration light stimulus sensitized the cell, making all subsequent currents relatively larger. Linear regression between the peak $I_{\text {Nalgt }}$ measurements and holding potential (excluding the first current measurement) revealed a conductance of $47.8 \pm 13.6 \mathrm{nS}$ and a reversal potential of $80.2 \mathrm{mV}$. At depolarized potentials, the mean peak $I_{\text {Nalgt }}$ versus voltage for 30 msec light stimuli (Fig. $4 A$, solid triangles) paralleled that seen for $3 \mathrm{sec}$ light stimuli. However, the currents at hyperpolarized levels were smaller than expected. Again, this was likely attributable to a light-induced sensitization, which occurred over several light stimuli because of the 100 times briefer lights. The mean conductance of $I_{\text {Nalgt }}$, averaged over potentials between -60 and $0 \mathrm{mV}$, was $32.2 \pm 3.0 \mathrm{nS}$ for $30 \mathrm{msec}$ light stimuli.

To further evaluate the voltage dependence of $I_{\text {Nalgt }}$, the effect of voltage on time-to-peak was evaluated. The mean time-to-peak was $340 \pm 13.2 \mathrm{msec}$ for $3 \mathrm{sec}$ light stimuli and $362 \pm 13.3 \mathrm{msec}$ for $30 \mathrm{msec}$ light stimuli (Fig. $4 B$ ); it was not significantly affected by holding potential. The absence of voltage dependence for both $30 \mathrm{msec}$ and $3 \mathrm{sec}$ light stimuli supports the supposition that the departure from linearity of current amplitude is caused by sensi-

response to $30 \mathrm{msec}$ stimuli (solid triangles) and $3 \mathrm{sec}$ stimuli (open circles). $C$, Effect of $0 \mathrm{Na}^{+}$-TMA ASW on peak $I_{\text {Nalgt }}$ in response to $30 \mathrm{msec}$ stimuli (circles) and $3 \mathrm{sec}$ stimuli (squares). Solid symbols show the mean peak current in TMA; open symbols show the mean peak current measured in ASW. D, Mean peak $I_{\text {Nalgt }}$ in response to $30 \mathrm{msec}$ stimuli in ASW (open squares), TMA (solid circles), and ASW wash (stars) for the four cells held long enough to wash out the TMA. 
(A)

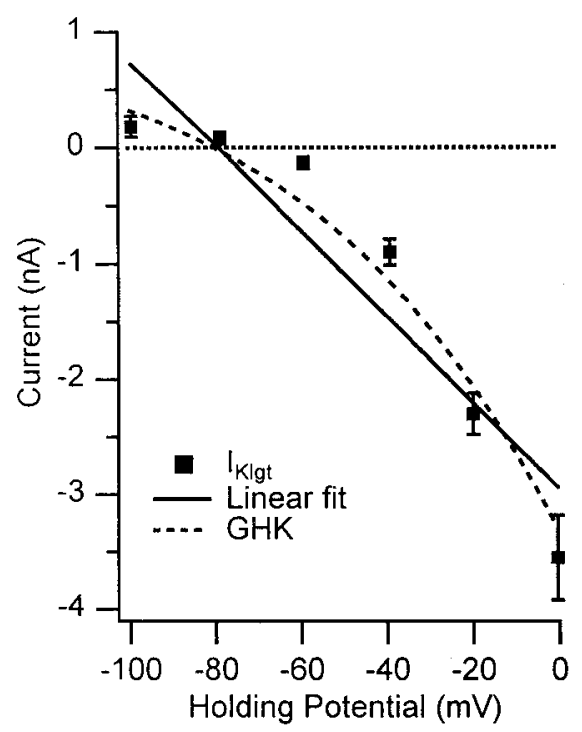

(B)

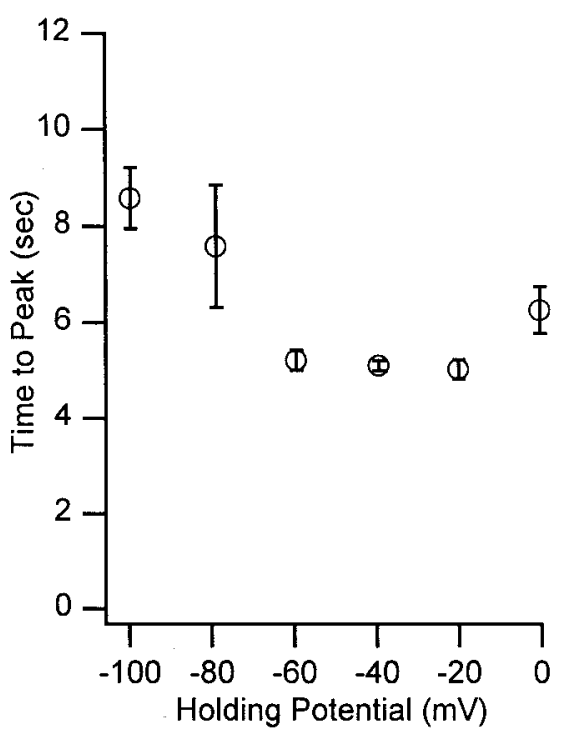

(C)

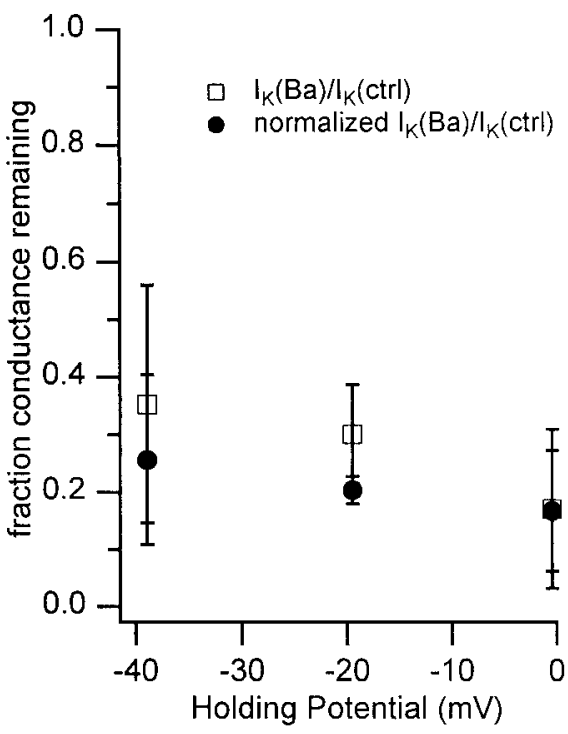

Figure 5. Characteristics of $I_{\mathrm{Klgt}}$. A, Mean peak conductance of $I_{\mathrm{Klgt}}$ in response to $3 \mathrm{sec}$ stimuli as a function of holding potential. The solid line is the regression line computed between individual peak $I_{\mathrm{Klgt}}$ measurements and holding potential. The dashed line is the best fit to the Goldman-HodgkinKatz equation assuming an internal potassium concentration of $240 \mathrm{~mm}$ (which yields a reversal potential of $-80 \mathrm{mV}$ ). Error bars indicated $1 \mathrm{SE}$. $B$, Mean time-to-peak of $I_{\mathrm{K} \text { gt }}$ in response to $3 \mathrm{sec}$ stimuli. $C$, Effect of $0 \mathrm{Ca}^{2+}-10 \mathrm{~mm} \mathrm{Ba}{ }^{2+}$ EGTA ASW on $I_{\mathrm{K} 1 g t}$. Open squares show the ratio of peak current in barium to peak current in ASW. Solid circles show the reduction of $I_{\mathrm{K} 1 \mathrm{gt}}$ caused by barium normalized by the increase in $I_{\mathrm{Nalgt}}$ caused by barium, to account for the increase in phototransduction second messengers caused by lack of calcium.

tization of phototransduction and not by voltage dependence of the channel itself.

$I_{\text {plateau }}$ was seen at hyperpolarized potentials with light durations of $3 \mathrm{sec}$ (Fig. 3A). To characterize the amplitude of and transition to $I_{\text {plateau }}$, a single exponential was fit to the sodium current from slightly after the peak time to light termination. In 2 of 17 cases, either the decay time was too long or a resurgent current delayed the start time such that the plateau value was not reached by light offset. For the remaining 15 cases, the mean time to decay to the plateau was $442 \mathrm{msec}$ at -80 and $425 \mathrm{msec}$ at -60 $\mathrm{mV}$. The $I_{\text {plateau }}$ amplitude was $22 \%$ of the $I_{\text {Nalgt }}$ peak. Values are reported at hyperpolarized potentials to ensure that $I_{\text {plateau }}$ measurements were not contaminated by $I_{\mathrm{Klg}}$.

\section{TMA blocks both the transient and plateau currents}

On a subset of cells, measurements were repeated with sodium replaced by TMA to demonstrate that the charge carrier for both $I_{\text {Nalgt }}$ and $I_{\text {plateau }}$ was sodium, and to isolate $I_{\mathrm{K} \text { lgt }}$. In response to $3 \mathrm{sec}$ light stimuli, a small residual $I_{\text {Nalgt }}$ remained, but $I_{\text {plateau }}$ was not evident in the absence of sodium (Fig. $3 B$ ). Figure $4 C$ summarizes the effect of TMA on $I_{\mathrm{Nalgt}}$ in response to $30 \mathrm{msec}$ (circles) and $3 \mathrm{sec}$ light stimuli (squares). TMA reduced $I_{\text {Nalgt }}$ in response to $30 \mathrm{msec}$ stimuli to $17.1 \pm 7.0 \%$ of its control value at $-60 \mathrm{mV}$. For $3 \mathrm{sec}$ stimuli, TMA reduced $I_{\text {Nalgt }}$ to $12.5 \pm 2.0 \%$ and $I_{\text {plateau }}$ to $15.9 \pm 3.9 \%$ of their control values at $-80 \mathrm{mV}$. The difference in these values was not significant $(\Delta=3.4 \pm$ $2.8 \% ; p=0.25)$, and the reduction of $I_{\mathrm{Nalgt}}$ was correlated with the reduction of $I_{\text {plateau }}\left(R^{2}=0.72 ; p=0.025\right)$, suggesting that these two currents were carried by the same channel. TMA did not have a significant effect on the time-to-peak of the residual current for $3 \mathrm{sec}$ light stimuli (mean difference $=3.4 \pm 21.1$ msec; $p=0.87$ ) or $30 \mathrm{msec}$ light stimuli (mean difference $=$ $13.9 \pm 8.2 \mathrm{msec} ; p=0.10$.)

\section{The effect of TMA washes out}

A subset of these cells was held long enough to wash out the TMA and repeat the measurements of the light-induced currents in ASW. In response to $30 \mathrm{msec}$ light stimuli, the currents measured in ASW-washed cells were similar to control currents (Figs. $2 C, 4 D)$. The mean value of the ratio of conductance after TMA to conductance before TMA was $1.23 \pm 0.11$; the difference between this ratio and 1.0 barely reached significance $(p=0.046)$ because of the large ratios at $-100(1.55 \pm 0.22)$ and $-80 \mathrm{mV}$ $(1.71 \pm 0.32)$. In response to $3 \mathrm{sec}$ light stimuli (Fig. $3 C$ ), either the TMA effect did not completely wash out, or the cell exhibited a general run down because of the length of the experiment. The mean conductance was $11.3 \mathrm{nS}$ during the $\mathrm{ASW}$ wash, which was significantly smaller than the $23.9 \mathrm{nS}$ observed before TMA $(t=$ 8.6; $p<0.0001)$.

\section{Characterization of light-induced potassium currents}

$I_{\mathrm{Klgt}}$ was the current remaining, other than the residual $I_{\text {Nalgt }}$, in TMA ASW (Figs. 2B,3B). Its amplitude increased with depolarization; it developed shortly after light onset and persisted for many seconds after light termination. For the cell illustrated in Figure $3 B$, a small current was apparent at $-69 \mathrm{mV}$. Neither this current, nor the current measured at $-49 \mathrm{mV}$ was likely to be caused by $I_{\mathrm{KCa}}$, as previously assumed, because that current requires depolarization to potentials greater than $-40 \mathrm{mV}$ for activation. The mean peak $I_{\mathrm{Klgt}}$ in response to $3 \mathrm{sec}$ light stimuli (Fig. 5A) was measured at least $2 \mathrm{sec}$ after light offset to minimize contamination by $I_{\text {Nalg. }}$. Linear regression revealed a conductance of $36.5 \pm 2.5 \mathrm{nS}$ and a reversal potential of $-80.2 \mathrm{mV}$ (Fig. $5 A$, solid line). The departure from linearity was accounted for by Goldman-Hodgkin-Katz rectification (Fig. 5A, dashed curve). The time-to-peak for $I_{\mathrm{K} l g}$, illustrated in Figure $5 B$, was considerably later than for $I_{\mathrm{Nalgt}}$. 
(A) ASW

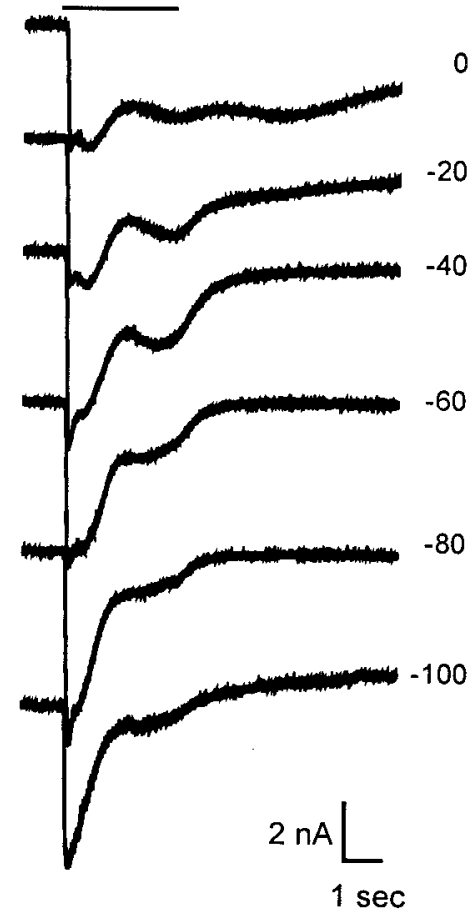

(B) $0 \mathrm{Ca}^{+}, 10 \mathrm{Ba}^{+}$, EGTAASW

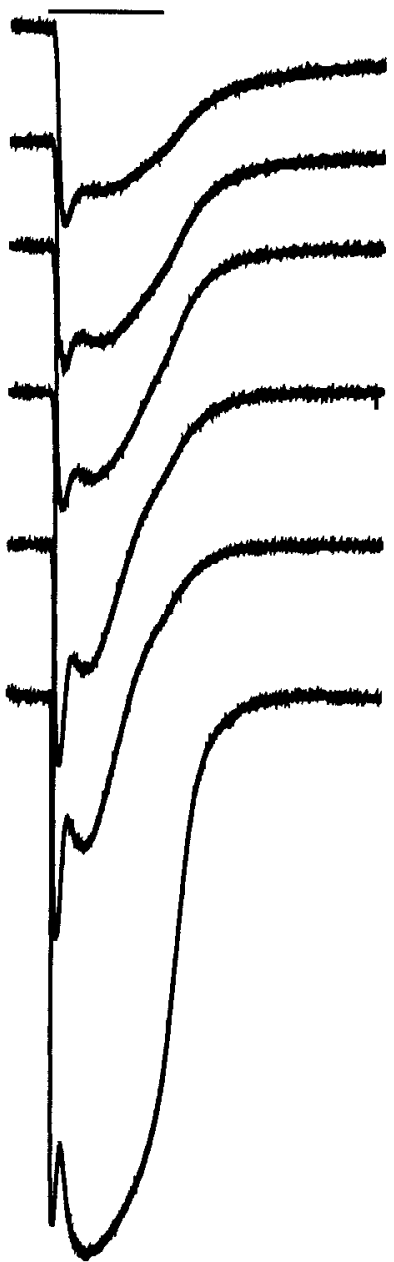

Figure 6. Effect of $0 \mathrm{Ca}^{2+}-10 \mathrm{~mm} \mathrm{Ba}^{2+}$ EGTA ASW on currents in response to $3 \mathrm{sec}$ light stimuli at holding potentials between -100 and 0 $\mathrm{mV}$. A, Total currents measured in ASW, different cell than in Figure 2. $B$, Currents measured in $0 \mathrm{Ca}^{2+}-10 \mathrm{mM} \mathrm{Ba}^{2+}$ EGTA ASW. $I_{\text {Nalgt }}$ is larger, $I_{\text {plateau }}$ has become a second peak current, and $I_{\mathrm{Klgt}}$ is reduced. The bars indicates when the light stimulus occurred. Traces are offset by an arbitrary amount.

\section{$0 \mathrm{Ca}^{2[\text { supi]+}}-10 \mathrm{Ba}^{2[\text { supi]+ }}$ ASW blocks the light-induced potassium current}

Measurements of the light-induced currents were repeated in 0 $\mathrm{Ca}^{2+}-10 \mathrm{mM} \mathrm{Ba}^{2+}$ EGTA ASW and revealed changes in all of the light-induced currents (Fig. 6). Both $I_{\text {Nalgt }}$ and $I_{\text {plateau }}$ were larger in the absence of calcium. In fact, $I_{\text {plateau }}$ was converted into a second peak at hyperpolarized potentials. The increase in sodium currents was attributable to the major role played by calcium in light adaptation. Light stimulation causes release of calcium from intracellular stores (Payne et al., 1990; Ukhanov and Payne, 1995; Talk and Matzel, 1996; Payne and Demas, 2000). The resulting elevation in calcium concentration serves to increase the rate of rhodopsin inactivation by arrestin (Dolph et al., 1993; Alloway and Dolph, 1999), decrease the phospholipase C activity (Smrcka et al., 1991), and likely has other roles in terminating phototransduction. Despite the dramatic effect on $I_{\mathrm{Nalgt}}$ and $I_{\text {plateau }}$ amplitude seen in this figure, the increase did not reach significance, possibly because of the small sample size $(N=4)$. Only four cells were collected under these conditions because the
(A)
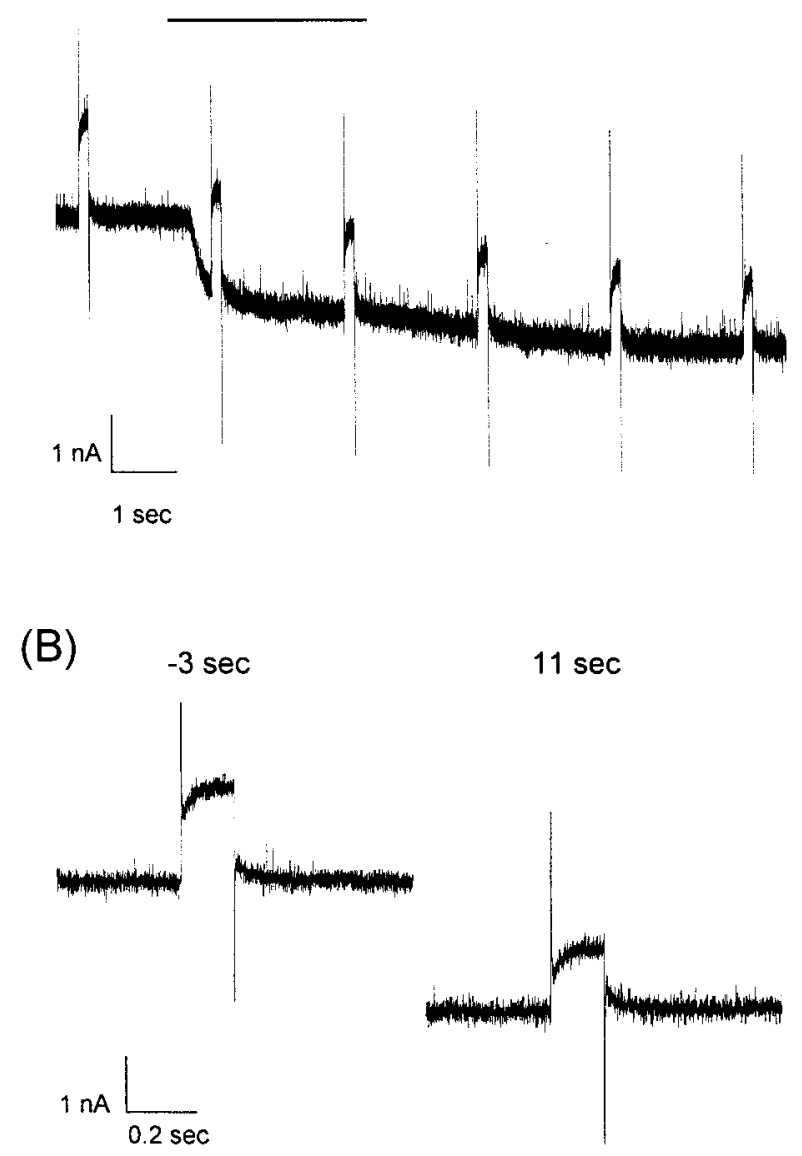

(C)

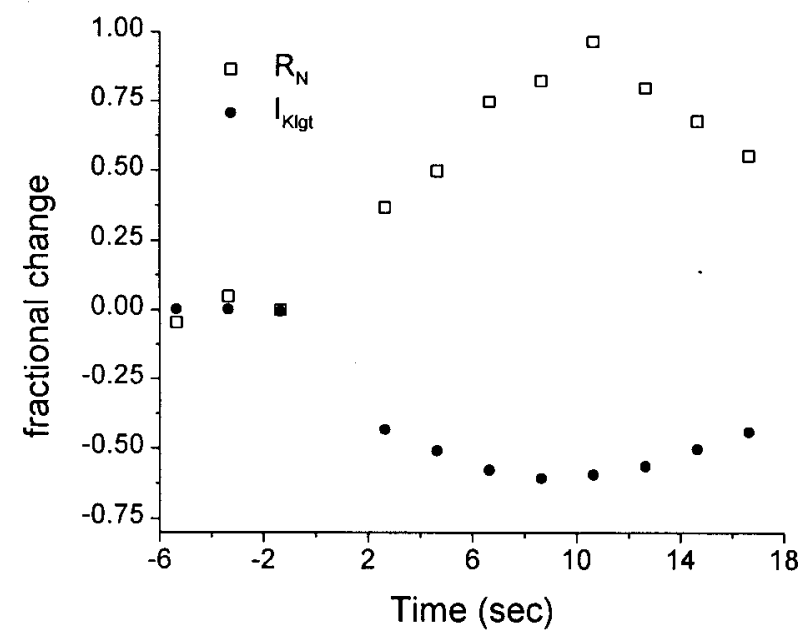

Figure 7. Effect of light on $R_{\mathrm{N}}$. A, Voltage-clamp current at holding potential of $-20 \mathrm{mV}$ in response to $3 \mathrm{sec}$ light stimulus of ND 0 . Voltage was stepped to $-10 \mathrm{mV}$ for $200 \mathrm{msec}$ every $2 \mathrm{sec}$ before, during, and after the light stimulus. The bar indicates when the light stimulus occurred. $B$, Segment of current trace from $3 \mathrm{sec}$ before light onset and $11 \mathrm{sec}$ after light termination to better illustrate the clamp current during the brief voltage steps. $C$, Fractional change in $R_{\mathrm{N}}$ and $I_{\mathrm{K} \text { lgt }}$ versus time for the cell illustrated in $A . R_{\mathrm{N}}$ measured between 6 and $14 \mathrm{sec}$ after the light stimulus is larger than that measured before the light. The change in $R_{\mathrm{N}}$ mirrors the change in $I_{\mathrm{Klgt}}$. 
Table 2. $I_{\text {KIgt }}$ had an extremely prolonged time course

Fraction of remaining current

\begin{tabular}{lllr}
\cline { 3 - 4 } Holding potential & Decay time & \multicolumn{1}{l}{$10 \mathrm{sec}$} & \multicolumn{1}{c}{$15 \mathrm{sec}$} \\
\hline$-40 \mathrm{mV}$ & $5.86 \pm 1.65 \mathrm{sec}$ & $0.715 \pm 0.093$ & $0.545 \pm 0.109$ \\
$-20 \mathrm{mV}$ & $10.0 \pm 2.54 \mathrm{sec}$ & $0.852 \pm 0.230$ & $0.634 \pm 0.206$ \\
$0 \mathrm{mV}$ & $7.86 \pm 1.93 \mathrm{sec}$ & $0.95 \pm 0.278$ & $0.58 \pm 0.144$ \\
\hline
\end{tabular}

The mean decay time constant and fraction of remaining current at 10 and $15 \mathrm{sec}$ for holding potential between -40 and $0 \mathrm{mV}$. Fraction of remaining current is the ratio of current at a particular time-to-peak current.

increase in phototransduction products interfered with estimating the effect of $0 \mathrm{Ca}^{2+}-10 \mathrm{~mm} \mathrm{Ba}{ }^{2+}$ EGTA ASW on $I_{\mathrm{Klgt}}$.

The second and more significant effect of $0 \mathrm{Ca}^{2+}-10 \mathrm{mM} \mathrm{Ba}^{2+}$ EGTA ASW was a reduction in $I_{\mathrm{K} 1 \mathrm{gt}}$ amplitude, illustrated for depolarized potentials in Figure 5C (hollow squares). On average, $0 \mathrm{Ca}^{2+}-10 \mathrm{~mm} \mathrm{Ba}{ }^{2+}$ EGTA ASW reduced $I_{\mathrm{K} 1 \mathrm{gt}}$ (measured at potentials between -40 and $0 \mathrm{mV}$ ) to $27.5 \pm 8.2 \%$ of its control value. To account for the increase in phototransduction second messengers caused by the elimination of calcium-mediated adaptation, the reduction in $I_{\mathrm{Klgt}}$ was normalized by the increase in
$I_{\mathrm{Nalgt}}$. This normalized $I_{\mathrm{K} \text { lgt }}$ reduction (Fig. 5C, filled circles) was slightly, but not significantly, smaller than the non-normalized current reduction.

\section{$\boldsymbol{I}_{\mathrm{KIgt}}$ is accompanied by an increase in $\boldsymbol{R}_{\mathrm{N}}$}

To confirm that $I_{\mathrm{K} \operatorname{lgt}}$ was caused by closure of potassium channels, $R_{\mathrm{N}}$ was measured every $2 \mathrm{sec}$ before, during, and after the light stimulus at potentials between -60 and $0 \mathrm{mV}$ in five cells. Figure 7, $A$ and $B$, shows current traces at $-20 \mathrm{mV}$ for one cell. Comparison of post-light measures with pre-light measures using repeated measures ANOVA showed a significant change in $R_{\mathrm{N}}$ over time $(F=6.85)$. Overall, $R_{\mathrm{N}}$ was reduced to $<40 \%$ of its pre-light value between 6 and $14 \mathrm{sec}$ after the light stimulus. To show that the change in $R_{\mathrm{N}}$ was attributable to a reduction in $I_{\mathrm{Klg}}$, the correlation was computed between $I_{\mathrm{K} \text { lgt }}$ and $R_{\mathrm{N}}$. Figure $7 C$ plots the values of $R_{\mathrm{N}}$ and $I_{\mathrm{K} \text { lgt }}$, determined every $2 \mathrm{sec}$ to show the correlation for the same cell illustrated in Figure $7 A$. The mean correlation over all cells and all potentials was $0.68 \pm 0.085$.

\section{Duration of $\boldsymbol{I}_{\mathrm{KIgt}}$ is similar to that of the LLD}

$I_{\mathrm{K} \text { lgt }}$ had an extremely prolonged time course: both the time-topeak was long, and the current remained for a very long duration

\section{(A) Effect of duration}

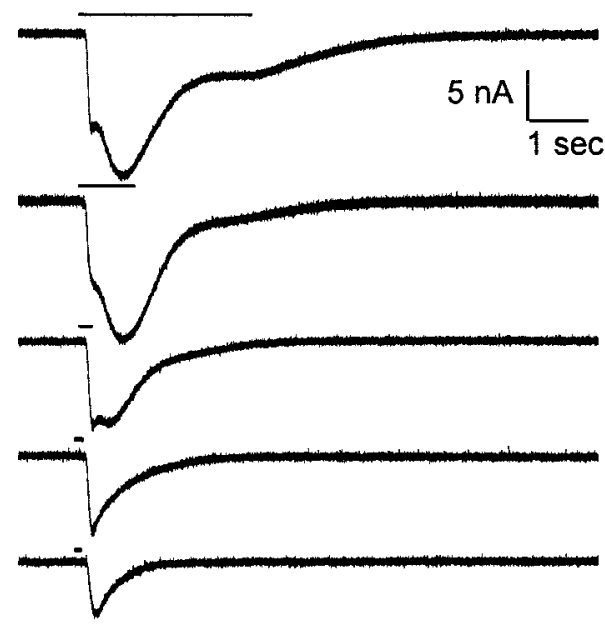

(C) $300 \mathrm{msec}$ light
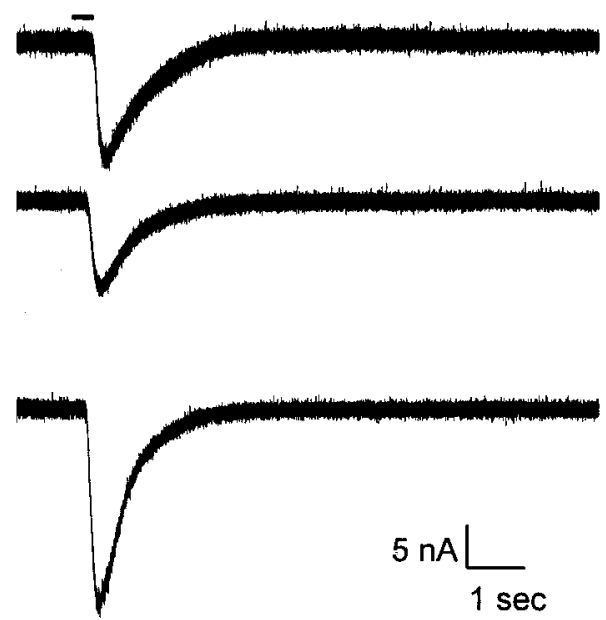

(B) 30 msec light

ND 2 ming

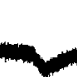

ND

ND 0

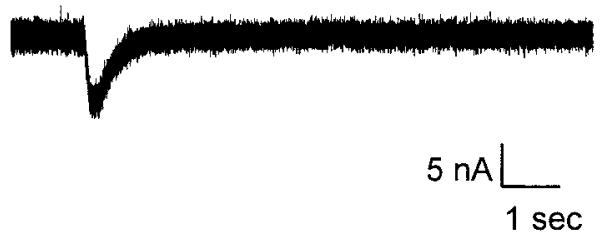

(D) 3 sec light

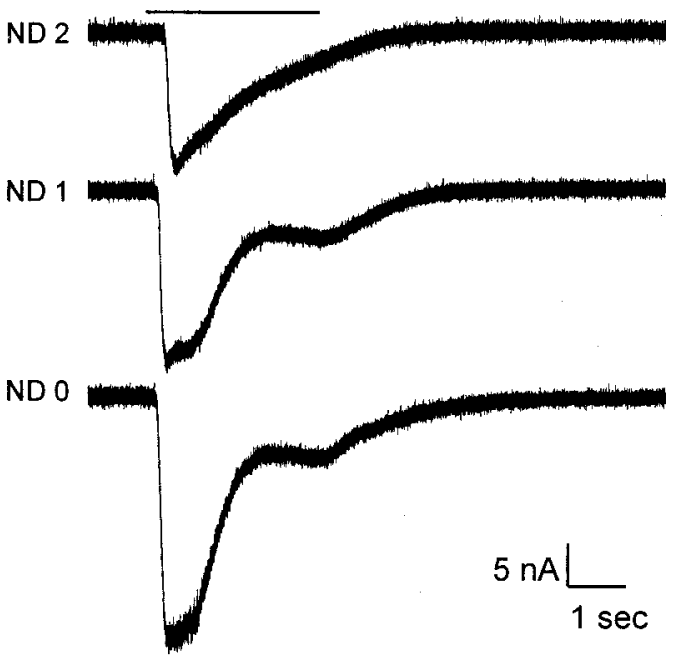

Figure 8. Effect of light intensity and duration on $I_{\text {Nalgt }} . A$, An increase in stimulus duration causes an increase in the peak conductance and rise time. $B-D$, The effect of intensity on $I_{\text {Nalgt }}$ for 30 msec stimuli $(B), 300 \mathrm{msec}$ stimuli $(C)$, and $3 \mathrm{sec}$ stimuli $(D)$. An increase in intensity causes an increase in the peak conductance and a decrease in the latency. The bars indicate when the light stimulus occurred. Traces are offset by an arbitrary amount. 
(A)

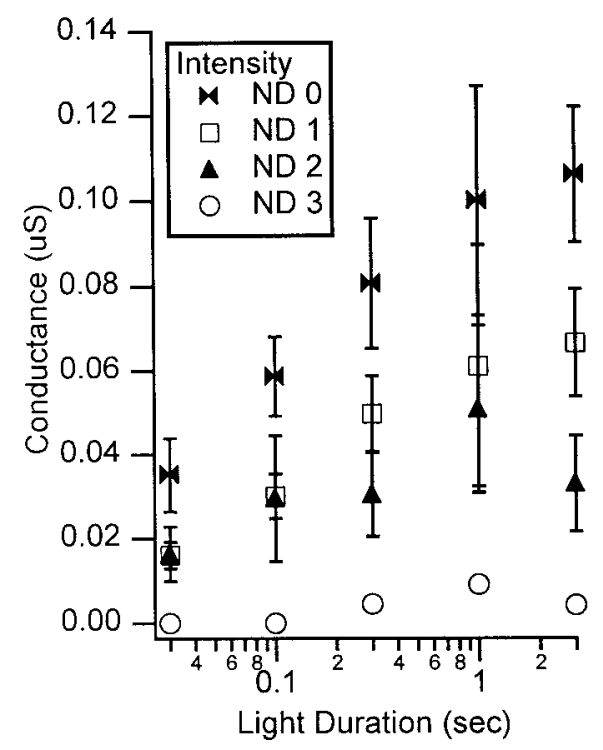

(B)

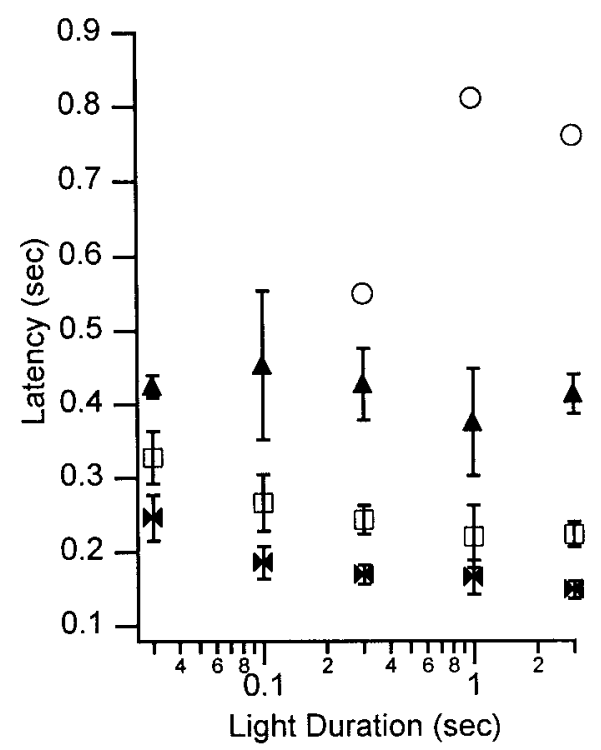

(C)

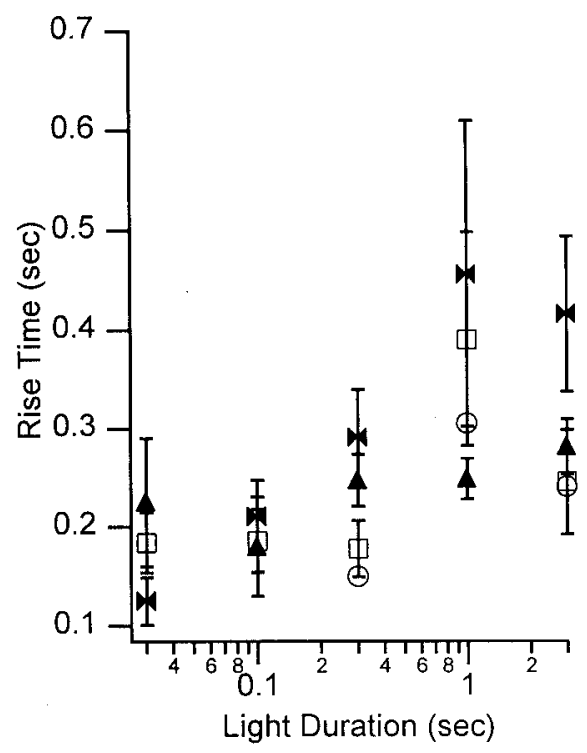

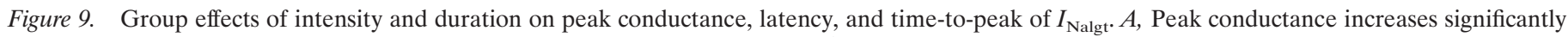

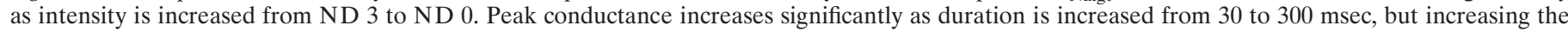

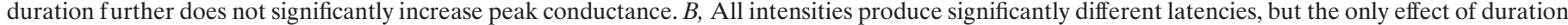

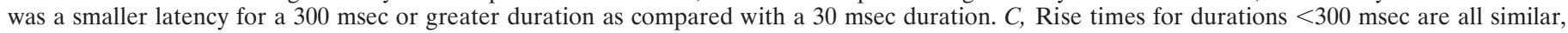
but rise times for 1 and $3 \mathrm{sec}$ stimuli are greater than that for stimuli of $\leq 300 \mathrm{msec}$.

after the peak time. To quantify the time course of $I_{\mathrm{K} \text { lgt }}$, the decay phase was fit with a single exponential. The start time of the exponential was no earlier than $2 \mathrm{sec}$ after the light offset to minimize contamination by $I_{\mathrm{Nalgt}}$. In cases in which the time course was more complex than a single exponential, the start time was delayed by several seconds to produce a good fit visually. The mean decay time constant was between 5 and $10 \mathrm{sec}$ for holding potentials between -40 and $0 \mathrm{mV}$ (Table 2). The decay time was so long that $I_{\mathrm{K} \operatorname{lgt}}$ was significant $15 \mathrm{sec}$ after light onset (12 sec after light termination), with the fraction of remaining current $>0.5$ (Table 2). To verify the characteristics of $I_{\mathrm{K} \text { lgt }}$ extracted in the presence of sodium currents, the exponential fits were repeated on $I_{\mathrm{Klgt}}$ measured in TMA ASW. The amplitude of $I_{\mathrm{K} \lg t}$ in TMA ASW at 10 and $15 \mathrm{sec}$ did not differ significantly from $I_{\mathrm{K} \text { lgt }}$ in control ASW ( $p>0.3$ for $\left.V \leq-40 \mathrm{mV}\right)$. The prolonged time course and voltage dependence (present at $-60 \mathrm{mV}$ ) makes it likely that this current underlies the baseline LLD.

\section{Effect of light intensity and duration on the sodium currents}

The effect of light intensity and duration on light-induced sodium currents was measured at a holding potential of $-80 \mathrm{mV}$. A longer duration light caused an increase in the peak conductance, as shown in Figure $8 A$. This particular cell had two current peaks for long duration lights, although this was not commonly observed. An increase in intensity caused an increase in the peak conductance and a decrease in the latency (the time between light onset and current onset), as illustrated in Figure $8 B-D$ for a 30 msec, $300 \mathrm{msec}$, and $3 \mathrm{sec}$ light (different cell than in Fig. $8 A$ ).

The effect of intensity and duration on peak conductance, latency, and rise time (the difference between time-to-peak and latency) for the group of cells is summarized in Figure $9 A-C$, respectively. Both intensity $(F=58.44 ; p<0.0001)$ and duration $(F=28.55 ; p<0.0001)$ had a significant effect on peak conductance (Fig. 9A). Peak conductance increased significantly as in- tensity was increased from ND 3 to ND 0. Peak conductance increased significantly as duration was increased from 30 to 300 msec $(p<0.0001)$, but increasing the duration further did not significantly increase peak conductance $(p=0.22$ between 300 msec and 1 sec duration; $p=0.63$ between 1 and $3 \mathrm{sec}$ light). Latency was significantly affected by light intensity $(F=50.69$; $p<0.0001)$ but only minimally influenced by light duration $(F=$ $3.3 ; p=0.04)$. As seen in Figure $9 B$, all intensities produced significantly different latencies, but the only significant effect of duration was a smaller latency for a $300 \mathrm{msec}$ or greater duration as compared with a $30 \mathrm{msec}$ duration $(p=0.013)$. Rise time was significantly affected by duration $(F=5.95 ; p=0.0003)$ but only minimally by intensity $(F=2.23 ; p=0.02)$. As shown in Figure $9 C$, rise time for durations $<300 \mathrm{msec}$ were all similar, but rise time for 1 and $3 \mathrm{sec}$ stimuli was greater than that for stimuli of $\leq 300 \mathrm{msec}$.

\section{$I_{\text {Nalgt }}$ inactivates for all duration light stimuli}

The observation that $I_{\text {plateau }}$ is blocked by TMA to the same degree as $I_{\text {Nalgt }}$ suggests that both currents are carried by the same channel and implies that the inactivation of $I_{\text {Nalgt }}$ is incomplete, and that $I_{\text {plateau }}$ represents steady-state equilibrium of both $\mathrm{IP}_{3}$ concentration and the fraction of open sodium channels. Under this hypothesis, the transition from $I_{\text {Nalgt }}$ to $I_{\text {plateau }}$ is caused by channel inactivation, whereas the decay of $I_{\text {plateau }}$ is caused by $\mathrm{IP}_{3}$ degradation. The latter predicts that decay of $I_{\text {plateau }}$ has a time constant similar to that of $\mathrm{IP}_{3}$ degradation. No plateau current is seen with very brief light stimuli, leaving open the possibility that the decay of $I_{\mathrm{Nalgt}}$ in response to $30 \mathrm{msec}$ stimuli is caused by $\mathrm{IP}_{3}$ degradation (Blackwell, 2000) or channel inactivation. These two alternatives are evaluated by comparing the decay time constant of $I_{\mathrm{Nalgt}}$ in response to a $30 \mathrm{msec}$ stimulus with that in response to a $3 \mathrm{sec}$ stimulus.

The decay time constants of $I_{\text {plateau }}$ and $I_{\text {Nalgt }}$ in response to 3 sec and $30 \mathrm{msec}$ stimuli were determined by fitting the current 
measurements to single exponentials. Results showed that the time constant of decay of $I_{\text {plateau }}$ was $3.6 \pm 1.0 \mathrm{sec}$, within the range of $\mathrm{IP}_{3}$ degradation rates measured in other cells (Allbritton et al., 1992; Wang et al., 1995), supporting the hypothesis that $I_{\text {plateau }}$ represents an equilibrium state of the channel that carries $I_{\text {Nalgt }}$. The results also showed that the $I_{\text {Nalgt }}$ decay time constant in response to $30 \mathrm{msec}$ light stimuli $(427 \pm 43 \mathrm{msec})$ was similar to that in response to $3 \mathrm{sec}$ light stimuli $(511 \pm 77 \mathrm{msec})$. There was no significant difference between these two values $(\Delta=$ $78.8 \pm 67.7 \mathrm{msec} ; p=0.2782$ ), whereas there was a significant difference between the decay time constant of $I_{\text {Nalgt }}$ in response to $30 \mathrm{msec}$ light stimuli and the decay time constant of $I_{\text {plateau }}(\Delta=$ $3.0 \mathrm{sec} ; p=0.0001)$. This demonstrated that decay of $I_{\text {Nalgt }}$, even for stimuli as brief as $30 \mathrm{msec}$, was caused by channel inactivation, not $\mathrm{IP}_{3}$ degradation.

\section{Effect of light intensity and duration on the potassium current}

The effect of light intensity and duration on light-induced potassium currents was measured at a holding potential of $-20 \mathrm{mV}$ in $0 \mathrm{Na}^{2+}-\mathrm{TMA}$ ASW. As shown in Figure $10 A$, a longer duration light caused an increase in the peak conductance, time-to-peak, and duration. An increase in intensity caused an increase in the peak conductance, time-to-peak, and duration for $30 \mathrm{msec}, 300$ msec, and $3 \mathrm{sec}$ light stimuli (Fig. $10 B-D$ ). In contrast with Figure 8 , no current was seen for ND 2 intensity at 30 or $300 \mathrm{msec}$, suggesting that $I_{\mathrm{K} \text { lgt }}$ was less sensitive to light than $I_{\mathrm{Nalgt}}$.

The effect of intensity and duration on peak conductance, latency, and time-to-peak of $I_{\mathrm{K} \text { gt }}$ for the group of cells is summarized in Figure $11 A-C$, respectively. Both intensity $(F=19.05 ; p<0.0001)$ and duration $(F=5.94 ; p=0.0003)$ had a significant effect on peak conductance, as shown in Figure $11 A$. Peak conductance was linearly related to the logarithm of intensity (slope $=-0.011 \pm 0.001 \mathrm{nA} / \mathrm{ND}$ ) and duration $(0.0087 \pm 0.002 \mathrm{nA} / \log \mathrm{sec})$. Comparison of Figure $11 A$ with Figure $9 A$ confirmed that $I_{\mathrm{Nalgt}}$ was more sensitive than $I_{\mathrm{K} \text { ggt }}$ : the minimum intensity-duration at which $I_{\mathrm{K} \text { gt }}$ appeared was 10 times greater than the minimum intensityduration at which $I_{\text {Nalgt }}$ appeared. Latency was significantly affected by light intensity $(F=8.28 ; p=0.0006)$, but was not significantly affected by light duration $(F=0.46 ; p=0.76)$. All of the effect of intensity was attributable to the difference between the ND 2 and ND1 intensities: there was no significant difference between the ND 0 and ND 1 intensities $(p=$ 0.5 ). Even at $-20 \mathrm{mV}$, the residual $I_{\mathrm{Nalgt}}$ (not completely blocked by TMA) probably obscured the beginning of $I_{\mathrm{K} \lg t}$, thus the lack of significance may not be reliable. Both duration $(F=13.17 ; p<0.0001)$ and intensity $(F=9.53 ; p<0.0001)$ had a significant effect on time-to-peak (Fig. 11C). Time-topeak was proportional to the logarithm of intensity $(-1.32 \pm$ $0.26 \mathrm{sec} / \mathrm{ND})$ and duration $(-1.72 \pm 0.28 \mathrm{sec} / \log \mathrm{sec})$.

\section{DISCUSSION}

Experiments were performed to characterize the light-induced currents active at resting potentials and to evaluate the effect of duration and intensity on the light-induced sodium and potassium currents of the type B photoreceptor of Hermissenda crassicornis. Three inward current components were observed: an early transient sodium current, $I_{\mathrm{Nalgt}}$, a plateau sodium current, $I_{\text {plateau }}$, and a prolonged potassium current, $I_{\mathrm{K} \operatorname{lgt}}$. The prolonged current was accompanied by an increase in $R_{\mathrm{N}}$, confirming that this current is caused by a reduction in potassium currents.
(A) Effect of duration

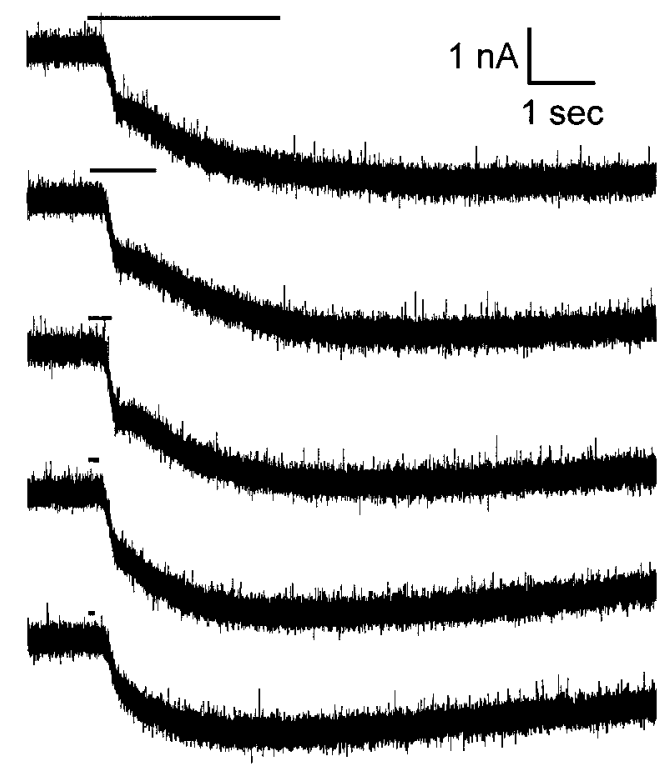

(B) $30 \mathrm{msec}$ light

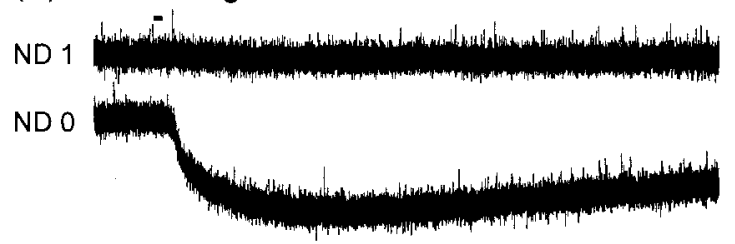

(C) $300 \mathrm{msec}$ light

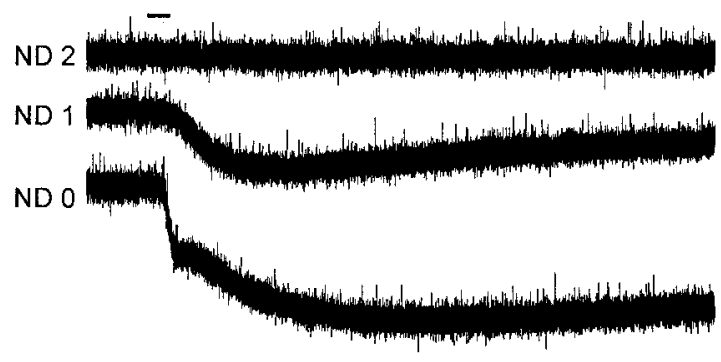

(D) $3 \mathrm{sec}$ light

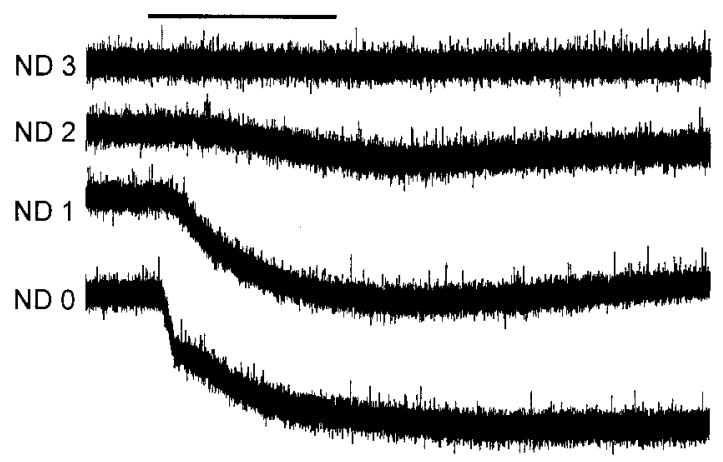

Figure 10. Effect of light intensity and duration on $I_{\mathrm{K} \text { lgt }} . A$, An increase in stimulus duration causes an increase in the peak conductance, timeto-peak, and duration of current. $B-D$, The effect of intensity on $I_{\mathrm{Klgt}}$ for a $30 \mathrm{msec}$ stimulus $(B), 300 \mathrm{msec}$ stimulus $(C)$, and $3 \mathrm{sec}$ stimulus $(D)$. An increase in intensity causes an increase in the peak conductance and time-to-peak. The bars indicate when the light stimulus occurred. Traces are offset by an arbitrary amount. 
(A)

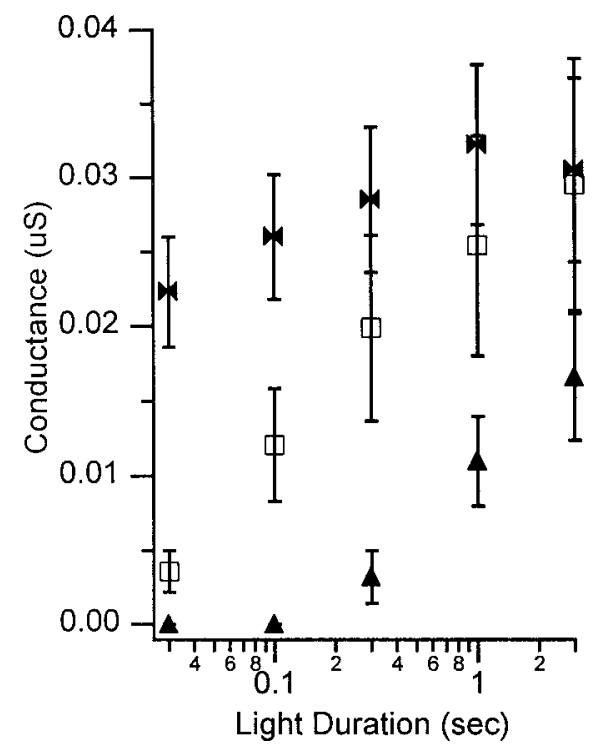

(B)

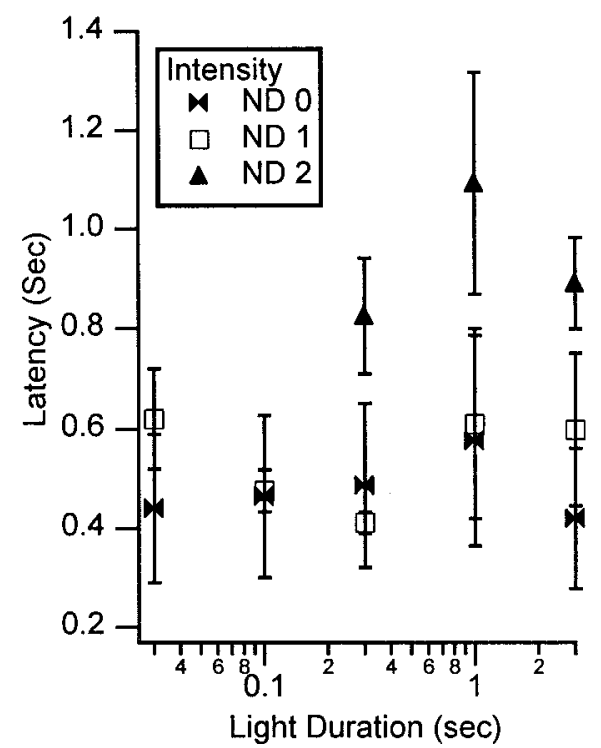

(C)

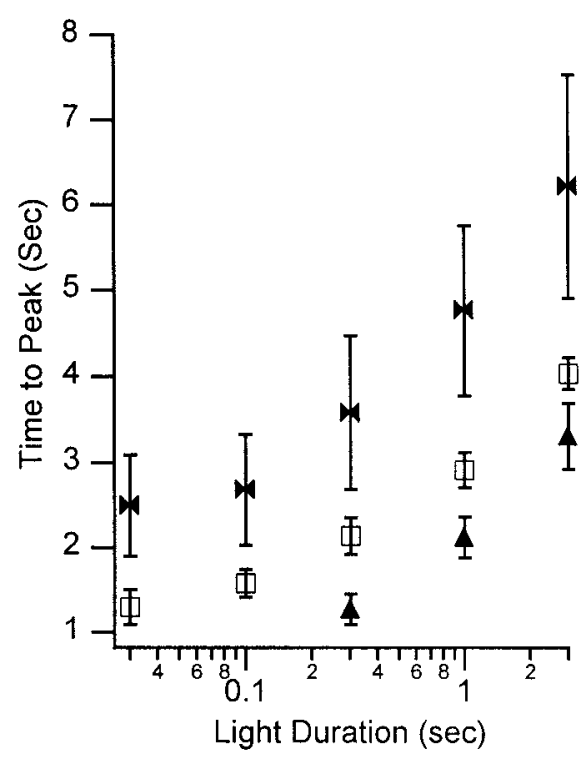

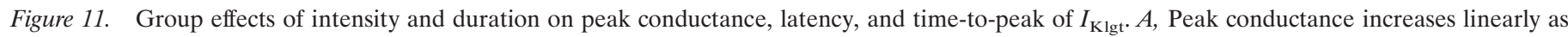

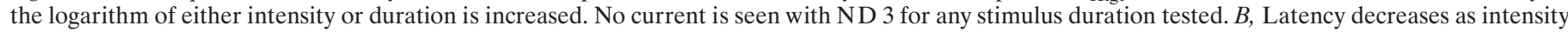

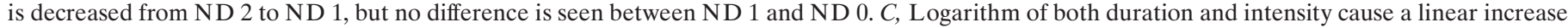
in time-to-peak.

The results confirm that $I_{\mathrm{Nalgt}}$ is independent of voltage. Its extrapolated reversal potential $\left(E_{\mathrm{Na}}\right)$ of $80 \mathrm{mV}$ is higher than previously reported estimates of $30-40 \mathrm{mV}$ (Alkon and Sakakibara, 1985). It is possible that $I_{\mathrm{Klgt}}$ contaminated the measurement of $I_{\mathrm{Nalgt}}$ at depolarized potentials and biased the $E_{\mathrm{Na}}$ estimate to more depolarized potentials; however, an $E_{\mathrm{Na}}$ of 80 $\mathrm{mV}$ is consistent with other measurements of $E_{\mathrm{Na}}$ (Amar et al., 1992; Johnston and Wu, 1995; Lapied et al., 1999).

$I_{\text {plateau }}$, observed for light durations of $3 \mathrm{sec}$, is blocked by TMA at hyperpolarized potentials demonstrating that it is a sodium current. It persists for the duration of the light stimulus and decays within $2 \mathrm{sec}$ of light termination. Thus, it contributes to the plateau potential during light, but not to the LLD observed after the light. The correlation between the fraction of $I_{\text {Nalgt }}$ blocked and the fraction of $I_{\text {plateau }}$ blocked by TMA suggests that these currents are carried by the same channel. $I_{\text {plateau }}$ is analogous to a window current and is caused by incomplete inactivation of $I_{\mathrm{Nalgt}}$ and a constant level of second messenger-dependent channel activation. The latter suggests that the biochemical reactions activated by phototransduction have reached equilibrium with the rate of second messenger production equal to the rate of degradation.

The time constants governing the decay of $I_{\mathrm{Nalgt}}$ and $I_{\text {plateau }}$ were analyzed to evaluate the role of channel inactivation and second messenger degradation. Inactivation of $I_{\mathrm{Nalgt}}$ had the same time constant in response to $30 \mathrm{msec}$ stimuli and $3 \mathrm{sec}$ stimuli, which suggested that channel inactivation is important in terminating phototransduction even for very brief light stimuli. The time constant of decay of $I_{\text {plateau }}$ was similar to the degradation time constant of $\mathrm{IP}_{3}$, the ligand of $I_{\mathrm{Nalgt}}$ (Sakakibara et al., 1998), suggesting that decay of $I_{\text {plateau }}$ is caused by degradation of $\mathrm{IP}_{3}$.

The most intriguing results of this study are the characteristics of $I_{\mathrm{Klg} \text {. }}$. Previous studies have concluded that $I_{\mathrm{Klgt}}$ is equivalent to $I_{\mathrm{KCa}}$ because a light stimulus reduces $I_{\mathrm{KCa}}$ measured in voltageclamp mode (Alkon and Sakakibara, 1985), and because both
$I_{\mathrm{KCa}}$ and $I_{\mathrm{Klgt}}$ have a fairly long time course. However, studies demonstrate that $I_{\mathrm{KCa}}$ becomes significant at potentials more depolarized than $-30 \mathrm{mV}$ (Alkon and Sakakibara, 1985; Farley, 1988; Sakakibara et al., 1993; Yamoah and Crow, 1995). Thus, $I_{\mathrm{KCa}}$ cannot be the source of the non-zero $I_{\mathrm{K} \operatorname{lgt}}$ current measured at -60 and $-100 \mathrm{mV}$ (observed in some cells) or the $-1 \mathrm{nA}$ mean current measured at $-40 \mathrm{mV}$. Furthermore, a computational modeling study of the Hermissenda photoreceptor evaluated the ability of light stimulation to activate $I_{\mathrm{KCa}}$ (Blackwell, 2000). The photoreceptor model included equations for calcium influx through voltage-dependent channels, calcium release from intracellular stores, $I_{\mathrm{A}}, I_{\mathrm{Nalgt}}, I_{\mathrm{KCa}}$ and $I_{\mathrm{Ca}}$, but did not include an explicit $I_{\mathrm{K} \text { lgt }}$. Simulations show that without an explicit $I_{\mathrm{K} \text { lgt, }}$, the simulated light response does not resemble the experimentally measured light response, suggesting that $I_{\mathrm{Klgt}}$ is distinct from $I_{\mathrm{KCa}}$.

Because $I_{\mathrm{K} \text { lgt }}$ is not carried by calcium-dependent potassium channels, it is necessary to identify the channel that does carry $I_{\mathrm{K} \text { lgt }}$. One possibility is the potassium leak conductance, $I_{\mathrm{K} \text { leak }}$, a channel that is independent of voltage, modulated by G-proteincoupled neuromodulators (Hsiao et al., 1997; Jafri et al., 1997; Talley et al., 2000) and blocked by barium (Buckler, 1999). The hypothesis that $I_{\mathrm{Klgt}}$ is caused by a reduction in $I_{\mathrm{Kleak}}$ is supported by the observation that $I_{\mathrm{K} \text { lgt }}$ is independent of voltage, other than the rectification predicted by the Goldman-HodgkinKatz equation and caused by unequal concentrations of potassium on either side of the membrane. Also, the observation that $I_{\mathrm{K} \operatorname{lgt}}$ is blocked by $0 \mathrm{Ca}^{2+}-10 \mathrm{Ba}^{2+} \mathrm{ASW}$ is consistent with this hypothesis, but it is not clear if the block is caused by the lack of calcium or the presence of barium. To better evaluate whether $I_{\mathrm{K} \text { lgt }}$ is attributable to a reduction in $I_{\mathrm{Kleak}}$, it is necessary to repeat measurements of $I_{\mathrm{K} \text { ggt }}$ in ASW with normal calcium concentration and $10 \mathrm{~mm}$ barium. It is entirely possible that the observed $I_{\mathrm{Klgt}}$ consists of two components, $I_{\text {Kleak }}$ and $I_{\mathrm{KCa}}$, which cannot be temporally separated. Measurements of $I_{\mathrm{Klgt}}$ in the 
presence of highly selective calcium-dependent potassium channel blockers will reveal the contribution of $I_{\mathrm{Kleak}}$.

The time course of $I_{\mathrm{K} \text { lgt }}$ is extremely prolonged, as reflected in the time-to-peak (Fig. $5 B$ ), the decay time (Table 2), and the fraction of remaining current at 10 and $15 \mathrm{sec}$ (Table 2). The time-to-peak of $I_{\mathrm{K} \text { lgt }}$ is considerably greater than that of $I_{\mathrm{Nalgt}}$, which suggests that either the second messengers that activate $I_{\mathrm{Klgt}}$ are downstream from those that activate $I_{\text {Nalgt }}$, or the kinetics of $I_{\mathrm{Klgt}}$ are slower than that of $I_{\mathrm{Nalgt}} . I_{\mathrm{Klgt}}$ is observed within $1 \mathrm{sec}$ of light stimulation when $I_{\text {plateau }}$ is blocked with TMA (Fig. $3 B)$; thus, under physiological conditions, the plateau potential seen with long-duration lights is a mixture of $I_{\text {plateau }}$ and $I_{\mathrm{Klgt}}$. The involvement of the potassium current (Farley, 1987) explains why the current observed from $1 \mathrm{sec}$ after light onset until light termination increases with depolarization.

Light intensity and duration had several effects on the lightinduced currents. An increase in duration and intensity caused an increase in the peak conductance of both $I_{\mathrm{Nalgt}}$ and $I_{\mathrm{Klgt}}$. The increase in $I_{\mathrm{Klgt}}$ was linear with the logarithm of duration and intensity, suggesting that the light quantities used were below saturation for $I_{\mathrm{Klgt}}$. This conclusion is consistent with the observation that $I_{\mathrm{K} \text { lgt }}$ was less sensitive to light than $I_{\mathrm{Nalgt}}$; the latter appeared at combinations of duration and intensity 10 times less than required for $I_{\mathrm{K} \text { lgt }}$. Other characteristics influenced by intensity and duration included latency of $I_{\mathrm{Nalgt}}$, which decreased with intensity, rise time of $I_{\text {Nalgt }}$, which increased with duration, and time-to-peak of $I_{\mathrm{Klg}}$, which increased linearly with the logarithm of duration and intensity. The duration of $I_{\mathrm{K} \text { lgt }}$ increased in relation to the time-to-peak; thus dim or short light stimuli produced relatively brief $I_{\mathrm{K} \text { lgt }}$ currents.

$I_{\mathrm{Klgt}}$ may play a role in the expression, but not necessarily the induction, of classical conditioning. Although an enhanced LLD is observed in type B photoreceptors of classically conditioned Hermissenda (Crow and Alkon, 1980; Farley and Alkon, 1982), neither the LLD nor cumulative depolarization is required for induction of membrane changes in the type B photoreceptor in response to conditioning. In vitro conditioning experiments demonstrate that induction requires a calcium elevation, but the primary source of calcium is release from intracellular stores, not influx through voltage-dependent channels (Matzel and Rogers, 1993; Talk and Matzel, 1996). Calcium and other second messengers (e.g., diacylglycerol and arachidonic acid) activate PKC, which phosphorylates potassium channels (Farley and Auerbach, 1986; Neary et al., 1986) and produces the increase in $R_{\mathrm{N}}$. However, expression of classical conditioning behavior involves suppression of type A photoreceptor activity by an increase in type B photoreceptor activity; thus the enhanced LLD may contribute to expression of classical conditioning by causing a post-light increase in type B photoreceptor activity. The properties of $I_{\mathrm{Klgt}}$ (the lack of voltage dependence and the prolonged duration) suggest that this current maintains the cell depolarized to a potential (the baseline LLD) at which the other potassium currents are active. Then, subsequent to classical conditioning, a reduction in voltage-dependent potassium currents causes an enhancement of the LLD. In addition to $I_{\mathrm{K} \text { gt }}$ the hyperpolarization activated inward current, $I_{\mathrm{H}}$, may contribute to the baseline LLD. $I_{\mathrm{H}}$ is active at resting potential and is enhanced by second messengers activated by serotonin (Acosta-Urquidi and Crow, 1993, 1995). If the LLD is required for the expression of classical conditioning behavior, then the sensitivity of $I_{\mathrm{Klgt}}$ to light intensity and duration provides limits to the light stimuli that will allow expression of classical conditioning in Hermissenda. Specifically, the light sensitivity of $I_{\mathrm{Klgt}}$ leads to the prediction that expression of classical conditioning requires light stimuli of sufficient intensity and duration to cause a prolonged $I_{\mathrm{Klgt}}$.

\section{REFERENCES}

Acosta-Urquidi J, Crow T (1993) Differential modulation of voltagedependent currents in Hermissenda type B photoreceptors by serotonin. J Neurophysiol 70:541-548.

Acosta-Urquidi J, Crow T (1995) Characterization of voltage-activated currents in Hermissenda type B photoreceptors. J Neurosci 15:319-332.

Alkon DL, Sakakibara M (1985) Calcium activates and inactivates a photoreceptor soma potassium current. Biophys J 48:983-995.

Alkon DL, Lederhendler II, Shoukimas JL (1982) Primary changes of membrane currents during retention of associative learning. Science 215:693-695.

Alkon DL, Farley J, Sakakibara M, Hay B (1984) Voltage-dependent calcium and calcium-activated potassium currents of a molluscan photoreceptor. Biophys J 46:605-614.

Alkon DL, Sakakibara M, Forman R, Harrigan J, Lederhendler II, Farley $\mathrm{J}$ (1985) Reduction of two voltage-dependent $\mathrm{K}^{+}$currents mediates retention of a learned association. Behav Neural Biol 44:278-300.

Allbritton NL, Meyer T, Stryer L (1992) Range of messenger action of calcium ion and inositol 1,4,5-triphosphate. Science 258:1812-1815.

Alloway PG, Dolph PJ (1999) A role for the light-dependent phosphorylation of visual arrestin. Proc Natl Acad Sci USA 96:6072-6077.

Amar M, Pichon Y, Inoue I (1992) Patch-clamp analysis of the effects of the insecticide deltamethrin on insect neurones. J Exp Biol 163:65-84.

Blackwell KT (2000) Evidence for a distinct light-induced calciumdependent potassium current in Hermissenda crassicornis. J Comput Neurosci 9:149-170.

Blackwell KT, Alkon DL (1999) Ryanodine receptor modulation of in vitro associative learning in Hermissenda crassicornis. Brain Res 822:114-125.

Buckler KJ (1999) Background leak $\mathrm{K}^{+}$-currents and oxygen sensing in carotid body type 1 cells. Respir Physiol 115:179-187.

Collin C, Ikeno H, Harrigan JF, Lederhendler II, Alkon DL (1988) Sequential modification of membrane currents with classical conditioning. Biophys J 54:955-960.

Crow T, Alkon DL (1980) Associative behavioral modification in Hermissenda: cellular correlates. Science 209:412-414.

Dolph PJ, Ranganathan R, Colley NJ, Hardy RW, Socolich M, Zuker CS (1993) Arrestin function in inactivation of $G$ protein-coupled receptor rhodopsin in vivo. Science 260:1910-1916.

Farley J (1987) Contingency learning and causal detection in Hermissenda: II. cellular mechanisms. Behav Neurosci 101:28-56.

Farley J (1988) Associative training results in persistent reduction in a calcium-activated potassium current in Hermissenda type B photoreceptors. Behav Neurosci 102:784-802.

Farley J, Alkon DL (1982) Associative neural and behavioral change in Hermissenda: consequences of nervous system orientation for light- and pairing-specificity. J Neurophysiol 48:785-807.

Farley J, Auerbach S (1986) Protein kinase C activation induces conductance changes in Hermissenda photoreceptors like those seen in associative learning. Nature 319:220-223.

Fost JW, Clark GA (1996) Modeling Hermissenda: I. Differential contributions of $\mathrm{I}_{\mathrm{A}}$ and $\mathrm{I}_{\mathrm{C}}$ to type-B cell plasticity. J Comput Neurosci 3:137-153.

Frysztak RJ, Crow T (1994) Enhancement of type B and A photoreceptor inhibitory synaptic connections in conditioned Hermissenda. J Neurosci 14:1245-1250.

Frysztak RJ, Crow T (1997) Synaptic enhancement and enhanced excitability in presynaptic and postsynaptic neurons in the conditioned stimulus pathway of Hermissenda. J Neurosci 17:4426-4433.

Hsiao CF, Trueblood PR, Levine MS, Chandler SH (1997) Multiple effects of serotonin on membrane properties of trigeminal motoneurons in vitro. J Neurophysiol 77:2910-2924.

Huang H, Farley J (2001) PP1 inhibitors depolarize Hermissenda photoreceptors and reduce $\mathrm{K}^{+}$currents. J Neurophysiol 86:1297-1311.

Jafri MS, Moore KA, Taylor GE, Weinreich D (1997) Histamine $\mathrm{H}_{1}$ receptor activation blocks two classes of potassium current, $\mathrm{I}_{\mathrm{K} \text { (rest) }}$ and $\mathrm{I}_{\mathrm{AHP}}$, to excite ferret vagal afferents. J Physiol (Lond) 503:533-546.

Johnston D, Wu X (1995) Foundations of cellular neurophysiology, Chap 6, Hodgkin and Huxley's analysis of the squid giant axon, pp 143-181. Cambridge, MA: MIT

Lapied B, Stankiewicz M, Grolleau F, Rochat H, Zlotkin E, Pelhate M. (1999) Biophysical properties of scorpion alpha-toxin-sensitive background sodium channel contributing to the pacemaker activity in insect neurosecretory cells (DUM neurons). Eur J Neurosci 11:1449-1460.

Lederhendler II, Alkon DL (1989) The interstimulus interval and classical conditioning in the marine snail Hermissenda crassicornis. Behav Brain Res 35:75-80.

Matzel LD, Rogers RF (1993) Postsynaptic calcium, but not cumulative 
depolarization, is necessary for the induction of associative plasticity in Hermissenda. J Neurosci 13:5029-5040.

Matzel LD, Schreurs BG, Lederhendler II, Alkon DL (1990) Acquisition of conditioned associations in Hermissenda: additive effects of contiguity and the forward interstimulus interval. Behav Neurosci 104:597-606.

McPhie DL, Matzel LD, Olds JL, Lester DS, Kuzirian AM, Alkon DL (1993) Cell specificity of molecular changes during memory storage. J Neurochem 60:646-651.

Muzzio IA, Talk AC, Matzel LD (1997) Incremental redistribution of protein kinase $\mathrm{C}$ underlies the acquisition curve during in vitro associative conditioning in Hermissenda. Behav Neurosci 111:739-753.

Neary JT, Naito S, De Weer A, Alkon DL (1986) $\mathrm{Ca}^{2+} /$ diacylglycerolactivated, phospholipid-dependent protein kinase in the Hermissenda CNS. J Neurochem 47:1405-1411.

Payne R, Demas J (2000) Timing of $\mathrm{Ca}^{2+}$ release from intracellular stores and the electrical response of Limulus. J Gen Physiol 115:735-748.

Payne R, Flores TM, Fein A (1990) Feedback inhibition by calcium limits the release of calcium by insositol triphospate in Limulus ventral photoreceptors. Neuron 4:547-555: 547-555.

Sakakibara M, Ikeno H, Usui S, Collin C, Alkon DL (1993) Reconstruction of ionic currents in a molluscan photoreceptor. Biophys $\mathrm{J}$ 65:519-527.

Sakakibara M, Inoue H, Yoshioka T (1998) Evidence for the involve- ment of inositol triphosphate but not cyclic nucleotides in visual transduction in Hermissenda eye. J Biol Chem 273:20795-20801.

Schuman EM, Clark GA (1994) Synaptic facilitation at connections of Hermissenda type B photoreceptors. J Neurosci 14:1613-1622.

Smrcka AV, Hepler JR, Brown KO, Sternweis PC (1991) Regulation of polyphosphoinositide-specific phospholipase $\mathrm{C}$ activity by purified $\mathrm{Gq}$. Science 251:804-807.

Talk AC, Matzel LD (1996) Calcium influx and release from intracellular stores contribute differentially to activity-dependent neuronal facilitation in Hermissenda photoreceptors. Neurobiol Learn Mem 66:183-197.

Talley EM, Lei Q, Sirois JE, Bayliss DA (2000) TASK-1, a two-pore domain $\mathrm{K}^{+}$channel, is modulated by multiple neurotransmitters in motoneurons. Neuron 25:399-410.

Ukhanov K, Payne R (1995) Light activated calcium release in Limulus ventral photoreceptors as revealed by laser confocal microscopy. Cell Calcium 18:301-313.

Wang SSH, Alousi AA, Thompson SH (1995) The lifetime of inositol 1,4,5,-triphosphate in single cells. J Gen Physiol 105:149-171.

West A, Barnes E, Alkon DL (1982) Primary changes of voltage responses during retention of associative learning. J Neurophysiol 48:1243-1255.

Yamoah EN, Crow $\mathrm{T}$ (1995) Evidence for a contribution of $\mathrm{I}_{\mathrm{Ca}}$ to serotonergic modulation of $\mathrm{I}_{\mathrm{K}, \mathrm{Ca}}$ in Hermissenda photoreceptors J Neurophysiol 74:1349-1354. 